\title{
PSYCHOLOGICAL PERSPECTIVES ON HATE CRIME LAWS
}

\author{
Megan Sullaway \\ Pacific Psychological Associates \\ University of California at Los Angeles
}

\begin{abstract}
Hate crimes are those in which the victim is selected because of his or her actual or perceived race, color, religion, disability, sexual orientation, or national origin. Hate crime laws have frequently been met with objections. Whereas some objections are based in constitutional law, other objections invoke a variety of psychological constructs, including attitude, motivation, behavior, emotion, and intergroup relations. These objections can be illuminated by relevant psychological theory and research. Topics addressed include the measurement of motivation and intent, and distinctions among attitudes, emotions, and behavior. Hate crimes and other crimes are compared in terms of perpetrators, type and degree of violence, psychological and physical trauma suffered by victims, and community impact. Psychologically based defense strategies used by perpetrators of hate crimes are critiqued. Hate crime laws are also discussed in terms of the political and social values they reflect. Finally, research and policy implications are outlined, including implications for prevention and intervention at the individual, community, and law enforcement levels.
\end{abstract}

Hate crimes can be broadly described as crimes in which the victim is selected because of the actual or perceived race, color, religion, disability, sexual orientation, or national origin of that victim. As states have enhanced penalties for hate-based crimes, various objections have been raised. Some objections are based in constitutional law (for review and discussion, see, e.g., Gerstenfeld, 1992; Levin, 1999; Winer, 1993). Other objections implicitly or explicitly invoke a variety of psychological constructs, including attitude, motivation, behavior, and emotion. These objections may be understood by examining findings from the psychological literature in the areas of assessment of behaviors and attitudes, aggression, victimology, and intergroup relations. The goal of this article is, first, to draw on this literature as it illuminates those objections that have a basis in psychological constructs and, second, to examine research and policy implications. The focus of this article is hate crimes against persons as opposed to against property. Hate speech regulations, as may exist on college campuses, are not the focus of this article.

Hate crime laws vary from state to state. California has numerous civil and criminal laws pertaining to hate crimes. A summary (Mikkelson, 1999; Noel, 2000) of selected civil and criminal laws in California that defines hate crimes, and describes penalty enhancements, officer training, and remediation is included in Appendix A. The Federal Hate Crime Statistics Act can be found in Appendix B. The hate crime laws addressed here typically apply when the perpetrator

The author thanks Meredith Watts for his feedback on an earlier draft of this article.

Correspondence concerning this article should be addressed to Megan Sullaway, Pacific Psychological Associates, 2221 Rosecrans Avenue, Suite 211, El Segundo, California 90245. E-mail: pacificpsych@aol.com 
commits an existing category of offense (such as assault or murder) that is ascertained to be motivated by prejudice or bias, in which case penalties may be enhanced.

The Supreme Court ruled in favor of hate crime penalty enhancement in Wisconsin v. Mitchell (1993). Its justifications were "although the government can't punish abstract beliefs, it can punish a vast array of depraved motives. .. . [Hate crime statutes do not] prohibit people from expressing their views, nor punish them for doing so..." The ruling suggests that hate crimes are more severe by nature than nonbias-motivated crimes, as they are "thought to be more likely to provoke retaliatory crimes, inflict distinct emotional harm on their victims, and incite community unrest."

Recent critics of hate crime laws argue that such "may not promote social harmony but, to the contrary, may reinforce social divisions and exacerbate social conflict" (Jacobs \& Potter, 1998, p. 145). In general, the concerns expressed about enhanced penalties and stand-alone statutes include the difficulty of determination of intent and motive, the punishment of ideas and attitudes in violation of First Amendment rights, the elevation of hate motives above other criminal motives as more severe, the creation of a special victim class, the risk of providing mitigating factors by which an offender can argue for reduced penalties, and increased intergroup tension as a result of these laws (Gerstenfeld, 1992).

In the following sections, relevant psychological theory, methodology and research findings are applied to these concerns.

\section{Difficulty in Determining Biased Intent or Motivation}

Critics of hate crime laws suggest that such laws are inevitably flawed because it is impossible to measure bias or to prove a causal relationship between prejudicial attitudes and behaviors.

Hate crime laws are different from most criminal laws in that they come into effect only when the offender has a particular motive. In most laws, there is some mens rea requirement, such as intent or recklessness, but the offender's motive for committing the crime is immaterial... assessing motive presents more than the problem of somehow reading the defendant's mind, for the defendant himself may not know his true motive. (Gerstenfeld, 1992, p. 269)

"For criminal conduct to constitute a hate crime, it must be motivated by prejudice and there must be a causal relationship [italics in orginal] between criminal conduct and ... prejudice." (Jacobs \& Potter, 1998, p. 21)

Implicit in this criticism are issues of definition (What is prejudice? Is it intent, motive, or both?), questions about measurement, and concern about ways in which causal relationships between internal states and behavior are determined. This includes concerns about the propriety of using motive to determine criminality and the possibility or impossibility of assessing motive.

\section{Prejudice, Hatred and Bias: Definitional and Measurement Issues}

Motivation or intent. Criminal law traditionally concerns itself with mens rea (literally, the reason for which one acts, the conscious intent) in assessing 
culpability. For example, the conscious intent of a person who breaks into a bank is to steal money. His underlying motivation might be to buy drugs (motive: getting high) or to help out his aged grandmother (motive: family loyalty) (example taken from Morsch, 1991). However, the motive is irrelevant as far as the determination of whether a crime has occurred (although it might conceivably be taken into account at sentencing). Morsch (1991) makes the argument that because hate crimes require a determination of motive ("why a perpetrator acted, not for what purpose or with what intent") and because motive is "inherently subjective, entirely within the contents of an individual's mind," (p. 659) hate crime laws are untenable.

Hurd, in congressional testimony (Hate Crimes Violence, 1999), makes a similar argument. Intent has, as its object, a perceived good. "To act so as to get money, or so as to subject another to sexual intercourse, or so as to kill someone is not (necessarily or intrinsically) to act on an emotion-it is rather to act so as to obtain what one perceives as a future good". In Hurd's view, the mens rea of hate crimes is uniquely motivational, and the motive is an emotional state. "Inasmuch as hatred is an emotion [italics in original] and bias is a disposition to make false judgments, both hatred and bias are quite different from the motivations with which defendants act when committing specific intent crimes." Hurd considers the emotion of hate and disposition of bias to be "dispositions possessed over time," for example, (in her view) "standing character traits," and concludes that therefore hate crime laws incorrectly criminalize vicious character traits as opposed to criminalizing certain goals or reasons for action.

In hate crime cases, however, intent and motivation have a much closer correspondence than that acknowledged by Hurd (1999) or Morsch (1991). Perpetrators may indeed commit hate crimes to achieve a particular future goal rather than to express an emotion, much as a thief steals to achieve a particular future goal rather than to express an emotion. For example, hate crimes may be committed to achieve a perceived future good, whether that is sending a message or discouraging in-migration of a particular group. Buford Furrow attacked a Jewish day-care center intending to send a message to all nonwhites and Jews. Umemoto and Mikami (2000) quote a member of the Loquitos gang explaining why the gang attacks African Americans who come into its neighborhood: "Three [murders] ain't that much ... Believe me, there should be a lot more dead ones. They know if they come into our neighborhood they better get the f--- out... there ain't no blacks here and there never will be." The statements made by perpetrators in these examples appear to satisfy Hurd's definition of intent, that is, acting "so as to obtain what one perceives as a future good." Watts (2001) has pointed out that in his research of German xenophobes, a strong theme is their goal of expulsion of foreigners from Germany. He also makes the point that "when the [German] government reacted by moving foreigners or changing laws, [the xenophobes] felt they had achieved part of their desired future good" (Watts, personal communication, October 2, 2001). These notions of future good may, to some eyes, be distasteful and illusory, but that does not mean they are not intent in the eyes of the law.

Lawrence (1999), citing Dressler (1987) and the Model Penal Code (American Law Institute, 1985), suggests that intent describes the mental state provided 
in the definition of an offense in order to assess the actor's culpability with respect to the elements of the offense.

The mental state that applies to an element of the crime we will call "intent," whereas any mental states that are extrinsic to the elements we will call "motivation." The formal distinction, therefore, turns entirely on what are considered to be the elements of the crime. What is a matter of intent in one context may be a matter of motive in another [italics added] (Hate Crimes Violence, 1999).

In a hate crime, the two concepts, intent and motivation, are virtually the same. For example, a bias-motivated perpetrator who assaults an African American may possess "a mens rea of purpose with respect to the assault along with a motivation of racial bias" or may possess "a first tier mens rea of purpose with respect to the parallel crime of assault and a second tier mens rea of purpose with respect to assaulting this victim because of his race" (Hate Crimes Violence, 1999). In either case, the situation describes a crime that could be penalized under hate crime statutes. ${ }^{1}$

The role of emotion in hate crime law. There are two issues implicit in Hurd's (1999) objection that "the mens rea requirement for hate or bias crime liability is an emotional state, not a reason for which one acts" (Hate Crimes Violence, 1999) One issue is whether the presence of a particular emotional state is necessary in order to define a crime as hate-based. A second, related issue is whether hate crime laws are unique in consideration of the emotional state of the perpetrator.

With regard to the first issue, the presence or absence of the emotion of hate is a poor criterion by which to define hate crimes. In a sense, "hate crime" is a misnomer, as many types of crimes involve hatred for the victim (although many do not, such as murders committed in the course of a robbery. The robber may have no particular feeling toward the victim other than a desire to not get caught.) Some perpetrators may plan and carry out hate crimes with little affective arousal. The absence of the emotional arousal characteristic of anger is most clearly evident in the case of psychopathic perpetrators. Psychophysiological monitoring of psychopaths indicates that they show decreased electrodermal responsiveness, less facial expression, the absence of affective startle modulation, and a higher likelihood of no startle reflex relative to nonpsychopaths (see, e.g., Herpertz et al., 2001).

Other perpetrators may commit hate crimes to experience the thrill, much as acts of vandalism or reckless driving may be committed for the thrill. The intent to act in such a way to experience that thrill is intrinsic to the crime. The emotion of hate, as defined by the presence of the physiological arousal characteristic of anger, may not be prominent relative to the more cognitive and deliberative

\footnotetext{
${ }^{1}$ Perhaps a close analogy to the intent issue in hate crime law is the intent requirement in stalking law in the state of California. In California, stalking can be charged as a felony. According to Cal. Penal Code $\S 646.9$ (2002), "Any person who willfully, maliciously, and repeatedly follows or harasses another person and who makes a credible threat with the intent to place that person in reasonable fear for his/her safety or the safety of his/her family, is guilty of the crime of stalking" [italics added]. As occurs in hate crime laws, criticisms of constitutional vagueness regarding the issue of intent have been raised, and the validity of the penal code has been upheld.
} 
process of victim selection based on the latter's membership in a despised group. Some have preferred the term bias-motivated crime. A change in terminology may be inconvenient but perhaps should be considered carefully.

Setting aside the points made above, consideration of the perpetrator's emotion is not unique to hate crime laws. Provocation doctrine, which has its origins in English common law, originally allowed reduction of a murder charge to manslaughter if the offender demonstrated that he responded in hot blood to an affront to his honor. The four accepted categories of affront included, for example, grossly insulting assault and catching another man in adultery with one's wife (Sing, 1999). Currently, provocation doctrine may be applied when four conditions are met: "(1) There must have been adequate provocation. (2) The killing must have been in the heat of passion. (3) It must have been a sudden heat of passion - that is, the killing must have followed the provocation before there had been a reasonable opportunity for the passion to cool. (4) There must have been a causal connection between the provocation, the passion, and the fatal act." (Perkins \& Boyce, 1982, cited by Mison, 1992, p. 140).

These distinctions are reflected in the law, in which first-degree murder includes malice aforethought, and manslaughter includes provocation or extreme emotional disturbance. Extreme emotional disturbance may mitigate murder when loss of control occurs that might be experienced by a reasonable person in that situation. According to the Model Penal Code

it is clear that...some external circumstances must be taken into account. Thus ... shock from traumatic injury, and extreme grief are all easily read into the term "situation"... it is equally plain that idiosyncratic moral values are not part of the actor's situation. An assassin who kills a political leader because he believes it is right to do so cannot ask that he be judged by the standard of a reasonable extremist." (Model Penal Code and Commentaries, 1985, 210.3)

In the case of homicide, therefore, the emotional state of the perpetrator may have significant implications for determination of the charge. In provocation or extreme emotional disturbance cases there is an examination of the mental and emotional state of the perpetrator, based on the evidence-in fact, emotional state is even more central to the definition of a crime under the rule of provocation than emotional state is to the definition of a hate crime.

Bias in victim selection. The mens rea in hate crimes is, in fact, the intent and goal of selecting particular victims because of group membership. Regardless of whether the emotion of hate is experienced during a hate crime, the choice of victim is a deliberate process, supporting Lawrence's (1999) point of a mens rea of purpose in victim selection. Evidence of planning, discussed below, would reinforce this point. Victim selection based on group membership is the issue, and selection implies choice and cognition. The emotion of hate is not central to the determination that a hate crime has been committed. Furthermore, laws defining hate crimes typically refer to bias in victim selection and are silent on the topic of perpetrators' subjective experiences of hate. For example, the Ralph Civil Rights Act (1976), provides that

it is a civil right for a person to be free of violence or its threat against the person or his or her property, because of a person's race, color, religion, ancestry, national 
origin, political affiliation, sex, sexual orientation, age or disability or position in a labor dispute, or because a person is perceived to have one or more of these characteristics. (Mikkelson, 1999)

Similarly, California's penal code provides additional punishment for felonies committed because of a victim's race, color, religion, etc., or because the victim is perceived to have one or more of these characteristics (Penal Code \$1170.75) and provides "a death penalty or sentence of life in prison without possibility of parole for murder because of the victim's race, color, religion, nationality or national origin" (Penal Code $\S 190.2(a)(16)$ ).

Measurement. As can be seen, the legal questions regarding intent versus motive in hate crime laws are complex. As a measurement issue, however, the assessment of intent and of motive are similar insofar as both require inference of internal processes. In the behavioral sciences, the issue of accurate measurement is a fundamental domain of study.

There is controversy not only about how concepts should be measured and the precision of those measurements, but there is also considerable controversy over the meaning of the constructs themselves. Intelligence, for example, as a concept or psychological construct, has no universally agreed upon definition among psychologists and educators. The measurement of intelligence is correspondingly problematic. (Green, 1992, p. 173)

By definition, abstract psychological constructs such as intelligence, prejudice, bias, or hatred are not directly observable. Rather, they must be inferred based on valid and reliable methods. There are various ways to do so. These include formal psychological testing (see, e.g., Anastasi \& Urbana, 1997), as well as behavioral observation, verbal reports of participants, or examination of archival records and behavioral traces (Sullaway \& Christensen, 1983). Prejudice as a psychological construct has been measured, predominantly, via psychological tests. The use of psychological testing to assess prejudice as an attitude or trait has been summarized by Dunbar (1995). Among the tests commonly used are scales to measure anti-Semitism (Selznick \& Steinberg, 1969), homosexual bias (Wright, Adams \& Bernat, 1999), and anti-Black racism (McConahay, 1986; McConahay, Hardee \& Batts, 1981). Other measured constructs include blatant and subtle prejudice (Pettigrew \& Meertens, 1995) and subtle racism against Blacks (Duckitt, 1991). However, many of these measures are vulnerable to self-presentation bias-in other words, the purpose of these measures may be transparent to the test taker, who may shape his or her responses to create a more acceptable presentation.

Another approach to the measurement of prejudice has been more unobtrusive in orientation. Harrison Goughs's (1951) studies of prejudice resulted in the creation of the Pr scale, consisting of items taken from the MMPI. The items, derived from a criterion-referenced keying strategy, reflect characteristics of anti-intellectuality, cynicism, pessimism, misanthropy, rigidity, dogmatism, discontent, and feelings of estrangement. Gough found significant correlations between prejudice scores and measures of anti-Semitism (Gough, 1951) and between prejudice scores and intolerance (Gough \& Bradley, 1993). Recent research 
strongly supports the construct and criterion validity of this scale (Dunbar, 1995; Dunbar, Saiz, Stela \& Saez, 2000).

Another unobtrusive methodology is the Implicit Association Test (IAT), which was developed to tap automatic, learned, hidden stereotypes that may bypass conscious awareness (Devine, 1989; Fazio, Jackson, Dunton \& Williams, 1995; Fazio, Sanbonmatsu, Powell \& Kardes, 1986). The degree of relationship between IAT-measured attitudes and behavior is, however, disputed (see, e.g., Karpinski \& Hilton, 2001, \& McConnell \& Leibold, 2001).

Behaviorally oriented psychologists offer a different set of measurement techniques. Within a behavioral framework, "the concept of personality represents a high level abstraction, which is nothing more than the sum total of the individual's behavior" (Goldfried \& Davison, 1976, p. 10). Therefore, the focus of a behavioral psychologist is operationalizing the construct of interest in terms of observable events, rather than attempting to infer unobservable constructs or traits. For example, parents may describe a problem child as defiant. A behavioral analysis would start by operationalizing the abstract trait of defiance in terms of specific, measurable, observable behaviors, such as cursing at a parent, failing to comply with a request, etc. A child described as mean would be monitored for specific behaviors including hitting others, breaking others' toys, etc. (Patterson, 1975).

Behavioral methods of measurement may include verbal (participant) report (in which participants report on their own and their peers' behavior) and behavioral observation (including ratings by trained observers of observable and definable behaviors captured live, on videotape or audiotape). Finally, archival records and behavioral traces may be used. These data are not generated for the benefit of the investigator, and may include, for example, "Court records of births, marriages, and divorces, personal diaries and letters, or patterns of carpet wear in the house" (Sullaway \& Christensen, 1983, p. 119).

\section{Determination of Causal Relationships}

Prejudice as a trait or attitude has been measured reliably using psychological tests. However, the presence of prejudice is not illegal, and such measurement techniques have little to tell us about the specific intent or motivation of an offender at the time of a crime. If prejudice or bias is to be determined insofar as it motivates or shapes criminal behavior, behavioral techniques are more appropriate and are quite compatible with the means routinely used by law enforcement agencies and the legal system to infer motives from various behaviors and behavioral traces. For example, the law "punishes seemingly similar conduct more severely based on an offender's motive. If a person enters a building to commit another crime while inside, it is burglary. If not, it is criminal trespass-a less serious offense" (Levin, 1999, p. 12). The motive is determined using behavioral traces, that is, evidence, such as the presence of tools to break into locked cabinets, a bag to carry the stolen goods, etc.

Similarly, the legal distinction between first- and second-degree murder is made based on the assessment of a suspect's motive and planning. These constructs (motivation and planning) might be operationalized as, for example, a witness's observation of the suspect staking out the victim's house, records 
indicating purchase of a weapon by the suspect in the week before the murder, a diary detailing the suspect's planning, etc. A behaviorally trained psychologist would identify these as "archival data and behavioral traces." Law enforcement and judicial personnel would refer to these data as evidence and infer motive or intent, accordingly.

When the Hate Crime Statistics Act of 1990 was passed, the FBI's existing Uniform Crime Reporting (UCR) Program was given the task of developing and implementing a hate crime data collection system for its voluntary law enforcement agency participants. The system collects information about the type of motivating bias, the nature of the offense, and victim and offender characteristics. According to the FBI report, "Hate crimes are not separate, distinct crimes, but rather traditional offenses motivated by the offender's bias . . . hate crime data can be collected by merely capturing additional information about offenses already being reported to UCR" (Federal Bureau of Investigation, 1999a, p. 1). Hate crime data are collected for 11 offense categories, including crimes against persons (murder and nonnegligent manslaughter, forcible rape, aggravated assault, simple assault, and intimidation), and crimes against property (i.e., robbery, burglary, larceny-theft, motor vehicle theft, arson, and destruction, damage/vandalism of property).

The determination of motive or intent is a central organizing principle for the UCR system. The Crime Classification Manual (CCM) of the FBI's National Center for the Analysis of Violent Crime (Douglas, Burgess, Burgess \& Ressler, 1992) categorizes eight index offenses on the basis of perpetrator intent and motivation. (Index offenses are those that are focused on by the National Crime Survey and tracked by the FBI and the U.S. Department of Justice, and include murder, rape, robbery, assault, personal larceny, burglary, household larceny, and motor vehicle theft.) The authors of the CCM decided "to base the classification on the primary intent of the criminal" [italics added] (p. $x$ ). The manual appears to use the terms intent and motive interchangeably.

The CCM describes a motivational model and a methodology to assess criminal motives based on forensic evidence. "(I)t becomes apparent that a blend of motivations inspire many violent crimes.... The approach taken in the CCM for multiple motives is to classify the offense according to the predominant motive" (pp. 6-7). (see Douglas et al., 1992) For example, extremist homicide is a murder "committed on behalf of a body of ideas based upon a particular political, economic, religious or social system" (p. 104). Political killings are motivated by doctrines or philosophies, religious homicide is motivated by "a fervent devotion to ... system of beliefs ..." (p. 104), and socioeconomic killing is "due to an intense hostility and aversion toward another individual or group that represents a certain ethnic, social, or religious group" (p. 104). In the context of such a concerted effort by the FBI to classify crimes based on perpetrator motive and intent, criticisms of hate crime legislation that claim the impossibility of assessing motivation are weakened.

With regard to the concern that it is impossible to determine if hate motives cause a crime, it should be noted that social science research acknowledges the impossibility of proving causal relationships in the absence of a controlled experimental paradigm in which potentially causal variables can be manipulated. In naturalistic observations of behavior, cause can only be inferred. However, this 
is as true of determining motivation for first-degree murder as it is for determining motivation for a hate crime. It is unrealistic to expect a higher standard of proof of causation for hate crimes than for other criminal conduct.

The challenge lies in the establishment of valid and reliable methods to determine the types of forensic evidence consistent with hate-based motivation. According to FBI data-collection guidelines (1999a),

\begin{abstract}
"Because of the difficulty of ascertaining the offender's subjective motivation, bias is to be reported only if investigation reveals sufficient objective facts to lead a reasonable and prudent person to conclude that the offender's actions were motivated, in whole or in part, by bias." [italics added] (p. 4)
\end{abstract}

The utility of hate crime statutes depends, in part, on the ability of law enforcement agencies to operationalize hate-based motives so that bias/hate-motivated criminal behavior can be described in specific and measurable ways (see, e.g., the 1998 recommendations of the International Association of Chiefs of Police). For example, police officers may be trained to look for the use of hate speech, hate propaganda, and expressed intent (verbal behavior). These pieces of evidence allow inference of hate as a motive for the criminal act.

There is some evidence that the absence of any competing more typical criminal motivations, such as theft, characterizes many hate crimes. Preliminary data exist concerning the associations between hate-motivated crime and material gain. In Los Angeles County, researchers working with the Criminal Conspiracy Section of the Los Angeles Police Department (LAPD) are attempting to profile the behavioral and community correlates of hate violence. Of all the reported hate crimes in Los Angeles County from 1994 to 1997, more than 80\% were not related to material gain as inferred by an absence of theft or robbery or alternative motivation. In other words, the sole apparent motivation was aggression against a member of the selected outgroup. Based on case-by-case analysis of crime reports written by arresting officers, in $74 \%$ of the hate crime incidents there was no provocation by the victim, and the victim was usually ( $76 \%$ of the time) a stranger to the perpetrator. These factors, in the absence of material gain, would seem to eliminate other possible common criminal motivations such as desire for revenge, personal provocation, robbery, and so on (Dunbar, Quinones, \& Crevecoeur, in press). Similarly, in a study of convicted bias-homicide offenders (Dunbar, Sullaway \& Krop, 2000) only 1 of the 46 murders was even partially motivated by material gain.

These findings, if confirmed by additional research, are material in responding to one of the criticisms of hate crime legislation, that is, determining whether a victim was selected for his or her "symbolic" versus "actuarial" status (Berk, 1990). For example, is a gay man targeted because of his sexual orientation per se, or because gay men are assumed to be easy targets, who may carry cash and may be reluctant to report the crime? (example from Berk, 1990). In the former case, sexual orientation is the raison d'être for the crime. In the latter case, sexual orientation is nothing more than a marker for an easy robbery victim, and the selection of the victim is seemingly more motivated by greed than by hate. When there is no material gain to the perpetrator and no other evident source of motive, it would seem possible to gauge with greater certainty the role of bias motivation. 


\section{Punishment of Ideas and Attitudes in Violation of First Amendment Rights}

"Is 'hate' to stand for a very specific idea or belief, or set of beliefs, with a very specific object or group of objects? Then waging war against it is almost certainly unconstitutional" (Sullivan, 1999). "Governor George Pataki signed a bill that imposes sterner sentences on criminals who go after their victims on the basis of race, religion, sexual orientation or age. . . What is being punished most severely is impure thought: bigotry" (Haberman, 2000, p. B4).

\section{Attitudes and Behavior}

Criticisms of hate crime statutes are sometimes flawed by conceptual confusion between attitudes and behaviors. For example, in his argument against the addition of extra penalties for hate crimes, Sullivan (1999) discusses the impossibility of eradicating hate and mingles discussion of the historical persistence of prejudicial attitudes with discussion of the futility of added penalties for hatebased criminal behavior. Similarly, Hurd (Hate Crimes Violence, 1999) believes that hate crime laws penalize having certain emotions, and that hate crime legislation that punishes persons for vicious character traits is "a dangerous and illiberal role for the State to take."

It is a conceptual error to cite (as does Sullivan (1999), above) the intractability of hate and prejudice and the difficulty or impossibility of eradicating it as rationales to discount the need for added penalties for crimes in which victims are selected by membership in a hated group. Some have argued that prejudice is inevitable given ordinary categorization processes in cognition (Billig, 1985; Ehrlich, 1973; Hamilton, 1981; Tajfel, 1981). Also, hate for particular outgroups may always be with us; however, emotions and attitudes ${ }^{2}$ are not identical to behavior.

In fact, the psychological literature that concerns itself with the study and measurement of attitudes suggests that associations between attitudes and behaviors are frequently weak (Ehrlich, 1973). Distinctions are made between knowledge of cultural stereotypes, endorsement of cultural stereotypes, and prejudice displayed in observable behavior (Devine, 1989). The individual with measurably high prejudicial beliefs and attitudes may have absolutely no history of aggressive or criminal prejudicial behavior and extremely low probability of future engagement in such. Many, if not most people who hold what might be considered prejudiced feelings, attitudes, and beliefs will no more act on those feelings, attitudes, and beliefs in any criminal way than they would hold up a convenience store.

It would seem to be commonsense that most individuals with prejudicial attitudes and feelings against a particular outgroup are highly motivated to

\footnotetext{
${ }^{2}$ Attitudes have been described in a variety of ways in the psychological literature but generally are considered to be evaluations of people, issues, and objects. The tripartite theory of attitudes suggests three aspects: the cognitive (what you think about the object, person, or issue), the affective (how you feel about the object, person, or issue) and the behavioral (how you act or react to the object, person, or issue). This theory has been challenged, as some attitudes do not include all three components, and furthermore, the three components may not be consistent with each other (Fiske \& Taylor, 1991; Zanna \& Rempel, 1988).
} 
withdraw from and avoid any contact with members of the perceived outgroup (Sullaway \& Dunbar, 1996). This position was taken by the Pennsylvania Superior Court in response to a defense strategy in which feelings of disgust toward lesbians was offered as a murder defense: "A reasonable person would simply have discontinued his observation and left the scene" (Commonwealth v. Carr, 1990). In support of this, studies have found that once the proportion of Blacks in predominantly White neighborhoods reaches $25 \%$, White flight accelerates (Clark, 1993; Galster, 1990; Ottensmen \& Gleeson, 1992). White flight is arguably a more common type of response to integrated neighborhoods than firebombing - and White flight is not a criminal offense, regardless of the motivation or ideology of those moving away.

In contrast, evidence from the Los Angeles County Human Relations Commission suggests that many convicted perpetrators of hate crimes are career criminals who seek to engage with the object of their hate in an aggressive manner rather then avoid the objects of their disdain (Dunbar, King, \& Umemoto, 1999). For example, anecdotal observation by police and community-based organizations suggests that the gay bashing that occurs in West Hollywood (a predominately gay area of Los Angeles County) is frequently perpetrated by individuals who don't live there-and who must drive significant distances from their homes with the specific intent of hurting someone who is or who appears to be gay. During a drive of 30-60 min duration (not unusual in Los Angeles), the "heat of passion" may cool, but deliberate intent does not. Research to investigate the validity of this anecdotal observation by using the assailants' home addresses, the location of the crime, and calculating the driving distance to the crime scene is currently being conducted in Los Angeles County.

\section{Protected Speech as Evidence}

Hate crime statutes penalize the behavioral enactment of hate beliefs, attitudes, and feelings, as manifested by the selection of a victim(s)/target(s); such statutes do not penalize hateful beliefs and emotions per se. If a prejudiced individual wishes to express his or her beliefs in a public setting, the law has supported his or her right to do so. In 1977 the U.S. Court of Appeals in Chicago, citing protected speech, overturned a lower court ruling, thereby allowing a Nazi march in Skokie, Illinois. In Smith v. Collin (1978), the Supreme Court refused to deny the order of the Chicago Court of Appeals. Hate sites exist on the Internet, and books advocating racial violence (such as the Turner Diaries [MacDonald, aka Pierce], 1978) are published and are considered protected speech. According to a Supreme Court ruling, "offensiveness is insufficient basis to punish speech" (Texas v. Johnson, 1989).

In R.A.V. v. City of St. Paul (1992), a White juvenile burned a cross inside the fenced yard of an African American family. Among other charges was one under a "fighting words" ordinance, which the juvenile challenged. "Fighting words" refers to "conduct which itself inflicts injury or tends to incite imminent violence" (In re Welfare of S.L.J., 1978). The U.S. Supreme Court found that the "fighting words" ordinance was invalid because it prohibited otherwise permitted speech solely on the basis of the content of the speech. The court found that the St. Paul ordinance created content discrimination because it proscribed only certain fight- 
ing words that insult or provoke violence on the basis of race, color, creed, religion or gender, and not "fighting words in connection with other ideas- to the basis of political affiliation, union membership, or homosexuality ..." (Noel, 2000).

In People v. Superior Court (Aishman) (1995), defendants were convicted of assaulting a trio of Mexican men. One defendant's statement that he was "hitting home runs with Mexicans" and another defendant's tattoos which included a swastika and the phrase "Thank God I'm White," were used as evidence to support hate crime charges, even though the defendants alleged that their constitutional rights of free speech were thereby violated. The court accepted the state's construction that this evidence helped demonstrate that the attack was because of the ethnicity of the victims. In this case, speech was used as evidence, and not itself prosecuted under criminal statutes.

This hypothetical example clearly makes this distinction: A young man tells his friends he plans to drive to a predominantly gay area of town "to get some fags." He assaults a (presumably) gay individual with a baseball bat, steals nothing, and follows up the attack with spray-painted directives to "kill fags." The crime, assault, occurs in a context of hate motivation and specifically expressed intent to select and hurt a person perceived as gay. Evidence includes hate speech and evidence of planning ("get some fags"), hate propaganda (spray-painted graffiti), and the absence of an alternative competing motive such as theft. This evidence would make the crime eligible for the application of penalty enhancements. (Note that in this example motivation and intent appear inextricably linked, per Lawrence's 1999 argument.)

\section{Equivalence of Hate Motivation to Other Criminal Motives}

Critics have charged that hate crime laws are "unnecessary, unfair and unconstitutional" because prejudice is "no more morally reprehensible than other criminal motivations like greed, power, lust ... etc." (Jacobs \& Potter, 1998, pp. $79-80$ ). Why should penalties be added to hate crimes when a person killed in a hate crime is just as dead as a person killed for reasons of greed? Furthermore, do hate crime laws create a special class of victims without justification? ". . . another problem with the legislation is that it creates different classes of victims, thus bending the concept of equal protection under the law" (Haberman, 2000, p. B4).

Perhaps prejudice is no more morally reprehensible than any number of other criminal motivations. However, there is preliminary evidence that hate crimes do differ from other crimes in the degree and type of violence. Also, psychological, criminological, and sociological research suggests that hate crimes may create greater harm for the victim and the community at large compared with other types of crimes. These types of factors have historically been taken into account by the criminal justice system in determining punishment.

\section{Type and Degree of Violence}

Criminal behaviors motivated by hate toward a particular class of people appear to be qualitatively different from other comparable criminal acts. According to FBI data, there is not a strong correlation between hate crimes and total index crimes, nor between total hate crimes and total violent crimes, suggesting, 
if valid, that "hate crimes appear to have their own uniqueness, trends, distributions and might not be inferred from Uniform Crime Report (UCR) ${ }^{3}$ index crimes." The variable "total U.S. hate crimes" correlates only .085 ( $p=.000)$ with "total violent crimes," and does not correlate at all with "total index crimes" or with "total property crimes" $(r=-.0115, p=.633$ and $r=-.035, p=$ .144 , respectively (Akiyama \& Nolan, 1999, p. 8).

A summary of hate crime data from 1997 to 1999 (using the NIBRS records; Strom, 2001) showed that hate crimes were more likely to be crimes against persons $(60 \%)$ than crimes against property $(38 \%)$. In contrast, of all NIBRS offenses reported during this time, about $20 \%$ involved a violent offense as opposed to a property crime. According to an analysis using UCR data (Akiyama \& Nolan, 1999) between 1992 and 1996, approximately 90\% of hate-based crimes against persons were assaults, compared with approximately $20 \%$ of UCR crimes. When examining the percentage of assaults that were aggravated, $45 \%$ of hatemotivated assaults versus $30 \%$ of UCR assaults were aggravated assaults. (An assault is considered aggravated based on the presence of a weapon and the degree and extent of injury.)

However, there are significant problems with the FBI database, as discussed in some depth by McDevitt et al. (2000), and elaborated upon later in this article, limiting the confidence that can be placed in Akiyama and Nolan's (1999) conclusions.

According to some researchers (Levin \& McDevitt, 1993), hate crimes are more likely than crimes in general to involve multiple offenders, to cause injury, and to require hospitalization. This increased harm appears to be recognized by police officers. In a mail survey of 2,657 law enforcement agencies administered as part of a larger study (McDevitt et al., 2000), police officers overwhelmingly agreed that "Given similar assault/vandalism cases, bias assault/vandalism is generally more serious than non-bias assault/vandalism" (eighty-five to $90 \%$ of respondents agreed or strongly agreed with this statement).

Anecdotal reports and some empirical evidence suggest that attacks against gay men and lesbians are particularly violent relative to assaults in general. A 1999 report by the National Coalition of Anti-Violence Programs showed that even as antigay attacks in the United States decreased by $4 \%$ (over a 1-year period), assaults became more violent: A $71 \%$ rise in assaults and attempted assaults using guns, and a $47 \%$ rise in the use of bats, clubs, and other objects were reported for this period (Inytzky, 1999). It is not clear if this is a genuine increase or reflective of improved reporting. Similar findings were reported by Comstock (1991), Kiel (1965), and Miller and Humphries (1980). Of course, we do not know how representative these reports are, as many attacks may go

${ }^{3}$ The Uniform Crime Report (UCR) is a city, county and state law enforcement program that provides a nationwide view of crime based on statistics submitted by law enforcement agencies throughout the United States. Eight specific crimes are identified for reporting: murder and nonnegligent manslaughter, forcible rape, robbery, aggravated assault, burglary, larceny-theft, motor vehicle theft, and arson (Federal Bureau of Investigation, 1999a). The UCR system collects summary information on arrests and crimes reported to the police. The National Incident-Based Reporting System focuses on each individual criminal incident. It allows for the collection of detailed information about crime victims, offenders, and other circumstances of the crime. 
unreported by victims (Herek, Cogan \& Gillis, 2002). If true, however, it would suggest that hate crimes are qualitatively different than crimes in general.

\section{Type of Criminal Who Commits Hate Crimes}

Instrumental versus reactive violence. Cornell et al. (1996) hypothesized that those who commit instrumental violence can be distinguished from those who commit reactive violence. Instrumental violence is goal directed and relatively purposeful, and frequently targets strangers and acquaintances as opposed to intimates. A planned robbery is an act of instrumental violence. Reactive violence occurs in response to frustration and hostility, triggered for example by a perceived threat or provocation (see Berkowitz, 1993, for a review). A fight that breaks out between drunken men in a bar is an instance of reactive violence.

The distinction between instrumental and reactive violence may be useful in considering different types of hate crime offenders. In general, instrumental offenders have been found to be reliably distinguishable from reactive offenders based on violent criminal behavior and level of psychopathy, independent of the extent of prior criminal record, age, race, or length of incarceration (Cornell et al., 1996). (Psychopathy refers to "a cluster of personality traits and socially deviant behaviors: a glib and superficial charm, egocentricity, selfishness, lack of empathy, guilt and remorse, deceitfulness and manipulativeness, lack of enduring attachments to people, principles or goals, impulsive and irresponsible behavior, and a tendency to violate explicit social norms" [Hare \& Hart, 1993, p. 104], and is a good predictor of violence and recidivism [Salekin, Rogers, \& Sewell, 1996].)

An area in which little research has been conducted to date is the examination of the association, if any, between instrumental aggression and bias motivation. Specifically, is there greater preplanning and goal-directedness as the degree of bias motivation increases? In a sample of 58 convicted bias criminals in Los Angeles County, a positive relationship was found between bias indicators and instrumental aggression; furthermore, instrumentally aggressive bias offenders appeared to be solely in pursuit of social dominance rather than monetary or other material gain (Dunbar, Quinones, \& Crevecoeur, in press). Dunbar, Sullaway and Krop (2000) examined 46 convicted murderers who had shown bias motivation. Seventy-nine percent of these murders were instrumental in nature. The greater the bias component to the homicide, the more likely there was preoffense planning of the crime.

In McDevitt et al's (2002) typology of hate crime perpetrators, the mission offender (the type most committed to a bias ideology) commonly uses weapons such as baseball bats or guns. The presence of weapons suggests some degree of instrumentality or preplanning. Similarly, the most common type of hate crime perpetrator found by McDevitt et al., the thrill offender, aggresses against victims on the victim's turf: "In $91 \%$ of these thrill motivated cases, the perpetrators reported having left their own neighborhood to search for a victim in a gay bar, a temple in another part of town, or a minority neighborhood" (p. 307). Again, this is consistent with the notion that hate crimes are frequently instrumental in nature.

More study is needed to determine if strength of bias motivation is positively correlated with instrumentality. Such a relationship has significant implications for level of violence, recidivism risk, and possible rehabilitation. 


\section{Increased Victim Trauma}

Psychological trauma. There is evidence that the psychological impact on the victim differs between hate-motivated and nonhate-motivated assaults. Victims of violent hate crimes may be more severely traumatized than victims of comparably violent nonhate-based crimes. Herek, Gillis and Cogan (1999) compared psychological distress suffered by gay men and lesbians after a bias crime versus distress suffered by gay men and lesbians after a nonbias crime of comparable violence. Subjects who were recent victims of hate crimes suffered greater psychological distress than subjects who were recent victims of nonbiasmotivated crimes. After 5 years, subjects who had experienced a bias-motivated assault reported significantly greater levels of depression, traumatic stress, anxiety, and anger than did subjects who experienced nonbias-motivated assaults. Subjects who were victimized in a bias crime appeared more likely to "regard the world as unsafe, to view people as malevolent, to experience a relatively low sense of personal mastery" (p. 949) compared with other subjects. According to Herek et al., there is some evidence that it may take longer to recover from a hate crime than from a comparable nonhate crime.

Weiss, Ehrlich and Larcom (1991-1992) found that hate crime victims reported, among other behaviors, "trying to be less visible" and moving to another neighborhood. McDevitt (1999) cites data in which victims of assault (bias- and nonbias-motivated) were assessed one year after the crime was committed against them. Victims of bias assault reported significantly greater nervousness, anger, intrusions ("thinking about it when didn't want to"), and difficulty concentrating at work, compared with victims of nonbias motivated assaults.

There are possible theoretical explanations as to why victims of hate crime attacks may experience greater psychological trauma. Janoff-Bulman (1979) has distinguished between behavioral self-blame and characterological self-blame. Briefly put, crime victims in general suffer psychological distress because the comforting illusion of personal invulnerability, of the world as a reasonable and somewhat predictable place, is shattered. Behavioral self-blame is a means to re-establish a sense of control by attributing the event (correctly or incorrectly) in some degree to one's own behavior, which implies the ability to prevent a reoccurrence of the event. A rape victim engaged in behavioral self-blame concludes "well, I shouldn't have been out walking at night," or "I knew I needed to have better security for my home." In contrast, characterological self-blame is esteem-related. The cause of the event is attributed to one's own character. As one's character is not easily modified, this implies an uncontrollable risk of future victimization. A rape victim engaged in characterological self-blame concludes "this happened to me because I am a bad or weak person." Behavioral self-blame has been associated with higher self-esteem and perceived future avoidability of victimization in rape victims (Janoff-Bulman, 1982), whereas characterological self-blaming has been a predictor of depression (Janoff-Bulman, 1979) and poorer adjustment to rape (Hill \& Zautra, 1989).

Similarly, Delahanty et al. (1997) found that victims of motor vehicle accidents who had not been responsible for their accidents felt more long-term distress, more likelihood of post traumatic stress disorder, more intrusive thoughts at 6-month and 2-year follow ups, and greater fear that an accident could reoccur, 
compared with those who had some responsibility for their accidents. Apparently, the perception of responsibility allowed a sense of controllability, and those accident victims who were responsible for the accident perceived that they had the ability to prevent another accident.

According to this model, it is understandable that victims of hate crime assaults may experience greater distress relative to victims of assaults in general. The latter may be able to make some behavioral changes to minimize perceived future risk. They may even attribute the crime to bad luck, and assume that future risk for assault is correspondingly low: "I was just in the wrong place at the wrong time." However, if victimization is attributable to race, ethnicity, and so on, these are as immutable as character. Perhaps victims of hate crimes, who are targeted specifically because of their membership in a particular group, are less able to preserve an illusion of control, because the illusion of prevention is not available: he or she cannot change race, ethnicity, sexual orientation, and so forth, even if he or she desired to.

Research with women, ethnic minorities, and homosexual samples shows that attributing an event to discrimination is associated with greater psychological distress and a sense of less control and mastery (Herek et al., 1999; Ruggiero \& Taylor, 1997). Making an attribution to discrimination in the case of hate crime is virtually unavoidable for the victim.

Physical trauma. The existing data concerning whether victims of hate crimes suffer greater physical trauma relative to victims of other crimes are limited. Previously described FBI data suggested that hate crimes are more likely (relative to nonhate crimes) to be crimes against persons than against property and that hate crimes against persons are much more likely to be assaults (Akiyama \& Nolan, 1999). In congressional testimony, McDevitt (2000) reported that his research in the Boston area showed that victims of hate crime assaults were three times more likely to require hospitalization than victims of nonhate crime assaults (Hate Crime Prevention Act, 1998).

There is anecdotal evidence that hate crimes based on sexual orientation "are unusually bloody or gruesome" (Winer, 1993). Comstock (1991) quotes a staff physician at a San Francisco medical center who says that bias-motivated attacks against gays

"are vicious in scope and the intent is to kill and maim... Weapons include knives, guns, brass knuckles, tire irons, baseball bats, broken bottles, metal chains, and metal pipes. Injuries include severe lacerations requiring extensive plastic surgery: head injuries, at times requiring surgery, puncture wounds of the chest, requiring insertion of chest tubes removal of the spleen for traumatic rupture, multiple fractures of the extremities, jaws, ribs and facial bones. ..." (p. 46)

Systematic research into this question of greater physical harm to hate crime victims is needed.

\section{Increased Community Impact}

Any violent crime always has multiple victims: the individual(s) directly harmed, and his/her friends and families. A violent hate crime adds another 
victim: the more distally targeted group to which the victim(s) belong(s). When Buford Furrow shot children in a Jewish day care center in the San Fernando Valley in California and subsequently killed a Filipino-American postal worker, he intended to both harm those he shot and to "send a message" to all non-Whites and Jews. According to a report in the Los Angeles Times (O'Neill, 2000, p. B1) "prosecutors allege that Furrow told the FBI he was at war with the 'Jewish controlled' government, shot Ileto [the postal worker] because he wanted to instill fear in non-whites, and wished to kill nonwhite law enforcement officers." Subsequent to the attack on the Jewish day care center, synagogues and other Jewish centers felt obligated to increase safety measures to prevent any similar attacks from succeeding.

When violent hate crimes are not reported to the police, as may be the case if the victim doubts the police will be sympathetic to him or her, or if the victim is in terror of the police (as in the case of immigrants from countries where police are corrupt or otherwise not trusted), the entire community is placed at increased risk. "The realization that one's 'community' may be targeted because of it's [sic] immutable or prominent characteristics slowly erodes feelings of safety and security" (Boeckmann \& Turpin-Petrosino, 2002, p. 209).

Hate crimes may instigate retaliatory attacks, further harming communities. Retaliatory offenses are attacks based on revenge for real or perceived hate crimes, and "tend to have the greatest potential for fueling and refueling additional hate offenses" (McDevitt et al., 2002, p. 309). In analyzing hate crime patterns in particular sections of New York City, Green, Glaser, and Rich (1998) found a correlation between anti-Black and anti-White hate crime of .58, "suggesting cycles of attack and reprisal" (p. 88).

At least one analogue study (Craig, 1999) attempted to study the issue of vengeance in response to hate crime victimization by exposing subjects to a videotaped assault in which the race of the perpetrators was varied to reflect same-race assaults or assaults in which victim and perpetrator race differed. Viewers' emotional and attitudinal responses, including desire for vengeance, were studied. Unfortunately, the study has significant methodological problems, most significantly with the videotaped assault, which would not be characterized as a hate crime according to California state law (the study was conducted in California). Although differences were found between subjects as a function of subject race and the video to which they were exposed, it is unclear what conclusions can be drawn from the study.

\section{Defense Strategies Invoking Psychological Causes}

"A prejudiced offender might plea [sic] that he is less culpable [italics in original] than a 'cold-blooded' profit motivated criminal because he was indoctrinated by his parents and youthful peers... According to this account, his prejudice was imposed, not chosen, and should make him a candidate for a lesser punishment, not a greater one." (Jacobs \& Potter, 1998, p. 81). "One defense possibility is what one author has termed Racial Paranoia-Induced Delusional Disorder (RPIDD)" (Gerstenfeld, 1992, p. 272). 


\section{Prejudicial Indoctrination}

Currently there is no evidence that "indoctrination with prejudicial beliefs" creates hate-based criminal behavior. As discussed above, it would seem more likely that parental indoctrination of prejudicial beliefs would result in outgroup avoidance. An interesting sociological study of young members of skinhead gangs suggests that parental (especially paternal) absence and neglect are more likely to play a role in the adoption of racist beliefs than parental indoctrination (Ezekial, 1995). Hightower (1997) studied the role of childhood background in the development of racist attitudes. His findings indicated that racists reported disturbances in their parental relationships as well as in their ties with peers. They also had poorer interpersonal skills, poorer internal controls, and reduced cognitive resourcefulness. Turpin-Petrosino (2002) found hate group support among young people to be associated with prior participation in lawbreaking activities, and in the case of secondary students, with parental name calling.

Even if it could be demonstrated that hate-based criminal behavior is motivated by beliefs that were inculcated in childhood, it is unclear how that would be a mitigating factor. Rapists may be indoctrinated by parents or peers to show contempt for women. Similarly, perpetrators of crimes against federal employees may be indoctrinated by parents and peers to feel contempt for government. These supposed causes are not likely to be recognized as decreasing culpability. Individuals convicted of drunk driving are given enhanced penalties. The possibility that alcoholic parents raised them is not a mitigating circumstance.

\section{$R P I D D$}

RPIDD is a term proposed by Tesner (1991) to characterize some hate crime defense strategies. This "disorder" is compared by Tesner to a delusional disorder as described in the Diagnostic and Statistical Manual of Mental Disorders (4th ed.; DSM-IV; American Psychiatric Association, 2000) and refers to a delusional that members of the victim's group were dangerous and out to harm the offender. RPIDD or similar arguments have been made in a limited number of cases. For example, when Colin Ferguson killed six people in a Long Island train in 1993, his attorneys, William Kunstler and Ronald Kuby, proposed a "Black rage" defense, suggesting that "being exposed to racist treatment over a long period of time drove Ferguson to violence" (Gregory, 1994, p. 143). However, the psychiatrists who proposed the term Black rage to refer to long-term adjustments to racism (Grier \& Cobbs, 1968/2000), made it clear (when asked about this defense strategy) that the term is neither a diagnosis nor a psychosis (Gregory, 1994).

In Commonwealth v. Gilchrist (1989), a black stockbroker fired by his white employer returned the next day and killed the employer. Mental health professionals hired by the defense testified that the defendant suffered from "a longstanding personality disorder that led him to harbor irrational beliefs that he was being persecuted because he is black," and that the "stress of being fired, combined with his irrational beliefs ... triggered a temporary psychosis" (Tesner, quoting from contemporary news accounts, 1991, pp. $329 \& 141)$. This defense failed.

The RPIDD "diagnosis" has no basis in the medical or psychological literature. Neither a Medline search from 1990 to 2000 nor a search of the PsycINFO 
database (using a variety of search terms) revealed any references to the "disorder."

\section{Homosexual Panic}

A similar strategy, used in gay-bashing cases, is the homosexual panic (Dahir, 1999; Kelleher, 1999; Toolis, 1997) or gay panic (Black, 1999) defense. The origins of the notion of homosexual panic appear to be clinical studies from the 1920s by Edward Kempf (Chuang \& Addington, 1988). The cases presented by Kempf were characterized by "both the patient's terror of her or his attraction to homosexuality and her or his fear of heterosexuality" (Kempf, 1920/1976, quoted by Comstock, 1992, p. 84). Not one of Kempf's cases displayed physical violence.

According to Glick (1959), homosexual panic is the aversive response of an individual to a presumed same sex attraction, which is threatening due to the repressed and latent homosexuality of that individual. "The term should be used to refer to an acute episodic schizophrenic reaction accompanied by intense terror based on the patient's unconscious wish to present himself as a homosexual object with the expectation of dire consequences" (from the abstract). Glick described situations in which acute homosexual panic was precipitated by "appropriate sentimental conditions" such as close living quarters with a member of the same sex, or by a loss or a separation from such a person to whom the individual is emotionally attached, creating a state of anxiety and panic which may even include delusions of being controlled or under the influence of the other. "Periods of introspective brooding, self punishment, withdrawal and helplessness more accurately describe the acute homosexual panic than does a single 'passionate' fit of brutally beating or killing another person" (Comstock, 1992, p. 87). In light of this theory, it is interesting that at least one study found that homophobia in heterosexual men was correlated with sexual arousal to "gay" stimuli, as measured by penile erection. Nevertheless, the straight "homophobic" group did not differ from other subjects on a standardized measure of aggression (Adams, Wright \& Lohr, 1996).

The notion of homosexual panic originates in psychoanalytic theory and depends on analytic theories such as latent homosexuality, repression, unconscious conflict, projection, and displacement. In a 1988 review of the concept of homosexual panic Chuang and Addington (1988, p. 616) concluded that the term "should be permanently assigned to the junkyard of obsolete psychiatric terminology." It is not a mental disorder.

\section{Homosexual Advance}

Another defense that references the psychological state of the offender is the concept of homosexual threat or homosexual advance. This defense proposes that a sexual proposition by a homosexual provokes understandable reactions of fear and rage. (Note that this strategy is not the same as claiming self-defense against perceived risk of death, serious harm, kidnapping or rape.) This defense has been used successfully, as in Schick v. State (1991). A young man hitched a ride with the victim. After riding around for some time, the young man asked where he could obtain a particular sex act, and the driver responded "I can handle that." They continued to drive, stopped for cigarettes, then drove to a baseball field and 
voluntarily walked into the shadows together. When the victim attempted to embrace the young man, the young man kicked and stomped on him, and left him to die. Before he left the scene, he took the victim's money, returned to the car, and wiped it clean of fingerprints. A homosexual advance provocation was argued by the defense. The prosecution did not object, and the judge instructed the jury on voluntary manslaughter-which was the verdict returned by the jury.

\section{Problems With RPIDD, Panic, and Advance Defenses}

The psychological defense strategies outlined above-RPIDD, homosexual panic and homosexual advance-appear to be variations on insanity, diminished competence, extreme emotional disturbance, or provocation defense strategies. There are conceptual difficulties fitting RPIDD, homosexual panic, or homosexual advance defenses into these categories.

For example, the assertion seems to be that RPIDD and homosexual panic create such strong impulses as to undermine an offender's volition, that is, "the ability to make a choice or determine something" (Black's Law Dictionary, 2000, p. 1271). This seems unlikely, as neither RPIDD nor homosexual panic as described appears to accurately describe the level of impairment required for insanity or diminished capacity defenses, such as the severe psychopathology typically found when there is a judicial ruling of incompetence, which includes disorientation, impaired memory, poor judgment, thought and communication disturbances, hallucinations, delusions, and bizarre, unmanageable behavior (Nicholson \& Kugler, 1991). Neither RPIDD nor homosexual panic is a recognized psychiatric disorder.

Homosexual advance defenses seem to be variations on provocation or extreme emotional disturbance defenses (described previously). A homosexual advance defense essentially describes the crime as reactive in nature-unplanned, unanticipated, the product of emotions of the situation. Yet in many of the cases in which a homosexual advance defense is attempted the attack does not appear to be unplanned or unanticipated. For example, in Schick v. State (previously described) the young man himself asked for a particular sexual act and voluntarily walked with the victim to a secluded area before killing him, circumstances that appear more instrumental than reactive in nature.

The situations in which perpetrator emotion mitigates murder change inevitably with societal mores. In original provocation doctrine, not only did English common law describe the four accepted affronts, it detailed those affronts inadequate to allow reduction of a murder charge to manslaughter (e.g., "mere words" or "insulting gestures"). Similarly, when wives were legally the property of their husbands, contemporary law allowed that "adultery is the highest invasion of property" and therefore "if the husband shall stab the adulterer ... this is bare manslaughter" (not murder) (Sing, 1999). Current laws against spousal abuse and battery reflect a profound shift in these values. The existence of hate crime laws similarly reflects social and political values. Given increased societal acceptance of homosexuality, for example (as evidenced by increased legal recognition of domestic partnership, and in one state recognition of homosexual marriage), is it proper that (in some observers' opinions), "As the law now stands ... only a homosexual advance can mitigate murder to manslaughter” (Mison, 1992, p. 134), 
or that such an advance "in and of itself constitutes sufficient provocation to incite a reasonable man to lose his self control and kill in the heat of passion" (pp. 133-134)? Would the "reasonable person" referenced in the Model Penal Code react with violence to an advance? Or simply walk away? In other words, added penalties for such a hate crime are appropriate because a perpetrator's violent response is not that of a hypothetical "reasonable person."

Kahan (1998) argues that the operative emotion in such cases is not fear or panic but rather, disgust. "Whereas anger and fear react to transgression against one's own person, disgust takes aim at a more diffuse object, namely, the threat that open deviance poses to the status of those who faithfully abide by dominant norms" (Kahan, 1998, p. 10). Research conducted by Olatunji, Lohr, and Meunier (2002) suggests that homophobia is not associated with feelings of fear and panic. Rather, they found relationships between measures of homophobia and measures of negative attitudes about homosexuality and measures of disgust and contamination fear. The inference could be made that attacks in response to homosexual advances are based not in panic and fear, but rather in feelings of disgust and a desire to punish perceived deviance.

\section{Hate Crime Laws and Intergroup Tension}

Critics of hate crime laws fear that such laws "Balkanize"4 U.S. society, meaning that hate crime laws will further divide racial, ethnic, and religious groups and increase intergroup tensions, potentially leading to more violence (Gerstenfeld, 1992; Jacobs \& Potter, 1998). However, there is no evidence that hate crime laws further divide racial, ethnic, and religious groups and increase intergroup tensions.

\section{Cognitive Dissonance Models}

Gerstenfeld (1992) wrote that "social scientific research suggests that . . . the existence of hate crime statutes may actually increase bigotry" (p. 280) without, however, presenting any persuasive theoretical analysis or actual evidence that this has occurred. She extrapolates from cognitive dissonance theory (Festinger, 1957), a theory around which a large body of social psychological literature has grown. Cognitive dissonance occurs when a person holds two dissonant, or inconsistent, cognitions, potentially creating a state of unpleasant psychological tension. Inconsistent cognitions, especially those that are important to the individual, are psychologically aversive. This tension can be reduced in a number of ways, including changing cognitions, adding to cognitions, or altering the importance of cognitions. Cognitive dissonance has been studied with respect to persuasion and attitude change (for reviews, see Cooper \& Fazio, 1984; Wicklund \& Brehm, 1976).

\footnotetext{
${ }^{4}$ To "Balkanize" is "to divide (a country, territory, etc.) into small, quarrelsome, ineffectual states," referring to "Yugoslavia [sic], Rumania, Bulgaria, Albania, Greece and the European part of Turkey" (Dilithium Press, 1989). An examination of the history of the area (Glenny, 1993) makes it clear that the conflict in the Balkans, based in centuries-old geographical quarrels, divisions, historically varied political systems, and religions cannot truly be compared with intergroup tensions in the United States.
} 
According to Gerstenfeld (1992), the theory states that "people's actions are motivated by a drive to avoid discrepancies between cognitions. This might mean that a person unconsciously alters his attitudes (or motivations) to conform to his behaviors" (p. 270). Gerstenfeld suggests that "cognitive dissonance theory... predicts that a person convicted of a hate crime will only become more ardent in his beliefs" because of the discrepancy between punishment for his actions and his desire to believe himself not to be a bigot.

There are numerous problems with Gerstenfeld's (1992) reading of the theoretical model and the conclusions she reaches. Her references to drive and unconscious have more in common with Freudian theory than Festinger's (1957) theory, and she omits mention of the numerous and complex factors that influence whether or not dissonance will induce attitude change, including perceived choice, perceived freedom, commitment, aversive consequences, personal responsibility, foreseeability, effort justification, and so on. More important, her assumption that perpetrators of hate crimes desire to perceive themselves as nonbigoted is highly questionable. ${ }^{5}$ If a perpetrator does not have the desire to believe that he or she is not bigoted, if a perpetrator is in fact proud to be bigoted, there is no discrepancy, and hence, no dissonance. However, even if one accepted her premise that offenders do not wish to see themselves as bigots, cognitive dissonance theory would seem to suggest that the very act of committing a hate crime would create significant dissonance, and that to reduce dissonance the individual would have to increase his or her hostile attitudes, regardless of whether or not he or she was caught and punished. In any case, the research literature generally addresses cognitive dissonance in terms of attitude adjustment, not in terms of violent behavior. ${ }^{6}$

\section{Intergroup Tension and Hate Crime Laws}

Existing data fail to confirm the hypotheses that hate crime laws increase intergroup tension. The state of California has had multiple hate crime-related statutes on the books for more than a decade (see Appendix A). The Balkanization hypothesis would predict an increase in interethnic and interracial tension. Recently, the Public Policy Institute of California (PPIC), a private nonprofit organization "dedicated to objective, nonpartisan research on economic, social, and political issues" issued a report that is pertinent to this issue. The PPIC surveyed public opinion regarding ethnic and race relationships in California by conducting 10 statewide public opinion surveys of over 20,000 adults between April 1998 and May 2000 (Hajnal \& Baldassare, 2001).

\footnotetext{
${ }^{5}$ See, for example, the interview with William Pierce, author of The Turner Diaries (written as “Andrew MacDonald") (Cline, 2001). "Yes, we're a racist organization. We're opposed to nonwhite immigration, to multiculturalism and to all of these programs based on the idea that there's basically no difference between the races except skin color." Similarly, an 18-year-old arraigned in Westminster, California, for murder and commission of a hate crime wrote "I believe in white power. My race is better. I don't care what others think. I don't like minorities" (Ni, 1995, p. B1). More recently, the killer of a Sikh man in Mesa Arizona (Frank Roque) said "I'm an American. Arrest me and let those terrorists run wild" (Leonard, Walsh, Kelly, \& Collom, 2001; Ettenborough, Klawonn, $\&$ Leonard, 2001). It is difficult to detect shame in these remarks.

${ }^{6}$ Thanks to Meredith Watts for pointing this out.
} 
According to the PPIC study, Whites, Latinos, Asians, and Blacks are very aware of the dramatic demographic shift in California. Whites $(73 \%)$, Blacks (70\%), Asians (65\%), and Latinos (63\%) report noticing the changes in racial and ethnic makeup of their region, and large majorities of each group believe the immigrant population in California has been increasing. Significant group differences were found in opinions about affirmative action, immigration, and bilingual education. Nevertheless, all groups feel generally positive about race relations. Specifically, solid majorities of all groups agree that racial and ethnic groups in their region are getting along well (86\% of Asians, $81 \%$ of Whites, $81 \%$ of Latinos, and $80 \%$ of Blacks), and majorities of all groups expect race relations to improve in the future. This is not to say that intergroup tensions do not exist in California, simply that there is no evidence that they have increased with the enactment of hate crime laws.

At a national level, there have not been convincing statistical analyses that show an association between the enactment of hate crime laws such as the Hate Crime Statistics Act (1990), the Hate Crime Sentencing Enhancement Act (1994), and the Church Arson Prevention Act (1996) and increased intergroup tension. A failure to find associations between enactment of hate crime laws and intergroup tension is consistent with Intergroup Contact Theory (Allport, 1958; Pettigrew, 1998; Pettigrew, 2002), which holds that contact between groups reduces prejudice if certain situational conditions are present: equal status of the groups in the situation, common goals, no intergroup competition, and authority sanction. (If one considers hate crime laws to be "authority sanction" of peaceful coexistence, it could be argued that hate crime laws ultimately work toward reduction of intergroup tension.)

It does not seem appropriate to draw parallels between the interethnic conflict that has occurred in various places around the world and the establishment of hate crime laws in the United States. On the one hand is the open incitement and encouragement of intergroup hatred and violence by national figures such as Milosovic in the former Yugoslavia, Osama bin Laden in Saudi Arabia and Afghanistan, and various leaders in Rwanda. On the other hand is the establishment of laws in the United States designed to penalize aggression by members of one group against members of another group. The two circumstances hardly seem comparable.

\section{Research and Policy Implications}

\section{Measurement}

Psychological assessment tools can measure prejudicial attitudes and beliefs with some degree of reliability and validity. However, these tools have little relevance in evidentiary questions of intent and motive in the commission of a hate crime. Intent and motive are overlapping constructs when examined from the vantage point of psychological measurement. Psychology can contribute to the development and refinement of techniques to collect evidence that best captures the various motivations involved in hate crimes. However, few such attempts have been made.

The Hate Crimes Statistics Act (1990) mandated collection of statistics on the incidence of hate crimes in the United States. A recent report released by the 
Bureau of Justice Statistics comprehensively reviewed the quality and accuracy of national bias crime statistics based on analyses of national reporting patterns, surveys of law enforcement agencies across the country, and qualitative information about advocacy groups and bias crime reporting (McDevitt et al., 2000). The interested reader is referred there for more details. Suffice it to say that there are unique aspects to bias crimes that interfere with accurate data collection, for example, victims' reluctance to report, failure of law enforcement to appropriately document hate elements or to submit the information to the Uniform Crime Report Hate Crime reporting unit. The McDevitt et al. (2000) review suggests that bias crimes are most likely very underreported. For example, the states of Alabama, Mississippi, and Louisiana, historically bastions of segregation and organized hate based groups such as the Ku Klux Klan, reported no hate crime offenses in 1999, a finding that strains credulity.

Dunbar (2002) used a multidimensional rating approach to assess bias motivation using crime reports as data. Signifiers of bias intent included articulated beliefs about superiority, hate speech during the crime, use of hate symbols, and memberships or affiliations with like-minded others. Two raters achieved acceptable levels of agreement using this system. In a review of 976 reported hate crimes, hate speech was present in $62 \%$ of cases, written hate speech in $20 \%$, and hate graffiti in $16 \%$ of cases. Among convicted bias offenders, $87 \%$ used hate speech during the commission of the crime. With similar methodology, Dunbar et al. (2001) were able to rate offenders' bias motivation reliably, using observed behavior and behavioral traces as reported in offenders' records, including police reports.

If future studies replicate these findings, it would be appropriate to test these methods more thoroughly in the field. This approach is consistent with the recommendations of the International Association of Chiefs of Police (1998), who advises officers to "collect and photograph physical evidence such as hate literature, spray paint cans, threatening letters, and symbolic objects used by hate groups" (Turner, 1998). Police officers consider these pieces of evidence "unambiguous cues" of hate crimes (McDevitt et al., 2000). The FBI Crime Classification Manual describes in detail a methodology to assess criminal motives based on forensic evidence, and FBI (1999a, 1999b) data collection guidelines emphasize the importance of obtaining "sufficient objective facts" to determine the presence of bias.

Additional research to more clearly delineate the best practices of evidence collection to assess bias motivation must be conducted. For example, different police divisions may have widely divergent practices in their methods and practices of hate crime data collection (Boyd, Berk, \& Hamner, 1996). Boyd et al. (1996) compared two police divisions within a large urban police department and found differences in how officers were (or were not) trained, the presence or absence of institutional oversight of hate crime categorization, and so on. Multiple social factors appear to affect law enforcement participation in hate crime data collection, including organizational attitudes and beliefs, community relations, resources, individual attitudes and beliefs, and organizational commitment, among other factors (Nolan \& Akiyama, 1999). Consistency in data collection is crucial, and the "best practices" of officer training, supervision, etc., should be developed and codified in policy. 


\section{Classification of Hate Crimes}

Hate crimes may be grouped, or typed, by a variety of methods: by target (person vs. property), by victim group (race, ethnicity, sexual orientation, etc.), or by the degree to which the crime is instrumental or reactive in nature. For example, some have suggested that religious-based hate crimes are disproportionately more likely to be property crimes whereas sexual orientation-based hate crimes are disproportionately violent crimes against the person. However, more research is needed to improve the description of hate crimes, with the goal of replicating, validating, and extending proposed typologies. Fine-grained analyses would allow us to examine whether the "topography" of hate crimes differs depending on the outgroup targeted in the crime. Are anti-Semitic hate crimes different in pattern from hate crimes predicated on sexual orientation? Do perpetrators tend to differ as well? Is any particular group (e.g., homosexuals or racial minorities) more likely to suffer greater physical injury in a bias-motivated attack as has been reported by some? Psychology can contribute to answering these questions.

\section{Hate Crime Laws and Social and Political Values}

Forty-two states have hate crime laws that cover at least race, religion and national origin (Levin, 2002). Not surprisingly, there are inconsistencies between states in terms of which categories are covered. For example, despite preliminary data indicating that crimes against homosexuals may be particularly vicious, several states' hate crime laws do not include sexual orientation in their protected categories. These omissions do not reflect the evidence of harm caused by hate crimes to the immediate victim and the group to which the victim belongs, thereby infringing upon the civil rights of an entire group. Hate crime statutes should accurately reflect our state of knowledge about the groups commonly targeted.

Bias-motivated violence occurs in a context of environmental contingencies, ranging from the state-mandated discrimination of apartheid laws as they existed in South Africa, to the officially sanctioned discrimination of the segregated South in the United States, to unofficially condoned and accepted discrimination, and, finally, to state discouragement or punishment of bias-motivated discrimination and violence (Watts, personal communication, October 2, 2001). The legal and political environment may thus augment, inhibit, or be neutral toward biasmotivated violence. Individual behavior takes place in this context. To the degree that discriminative behavior (including bias-motivated violence) is codetermined by individual prejudice and situational factors (Duckitt, 1992-1993), hate crime laws may inhibit at least some individuals from violent manifestations of their beliefs. For example, McDevitt et al. (2002) suggest that thrill-seeking offenders may be deterred from repeating the crime if there is a strong societal response.

Yet even if hate crime laws have little deterrence effect, they nevertheless have a powerful symbolic role in communicating social and political values to individuals. Hate crime laws make a symbolic statement that, for example, the negative evaluation of homosexuality implicit in a gay basher's attack is unreasonable and neither normative nor proper in our society. "At issue is whom we should regard as low and contaminating - the persons singled out for attacks on 
the basis of their identities, or the persons who attack them for that reason" (Kahan, 1998, p. 1628).

Group position theory (Blumer, 1958, cited by Bobo, 1999) suggests that "prejudice involves more than negative stereotypes and negative feelings, that it involves most centrally a commitment to a relative status positioning of groups in a racialized social order" (Bobo, 1999, p. 447), and that this relative status is institutionalized. According to Bobo, Blumer argued that "change in a racial order would spring from a direct assault on that racial order from largely noneconomic and political forces" (Bobo, 1999, p. 452). "The evidence seems to me ... that such changes do not arise from inner considerations of industrial efficiency. Instead they arise from outside pressure, chiefly political pressures" (Blumer, 1965, p. 247 cited by Bobo, 1999). Hate crime laws might be considered an example of the political pressure mentioned by Blumer.

Critical race theory suggests that hate speech and hate-based violence are not only crimes against individuals but can also be viewed as terrorist acts against the entire group to which the individual belongs. Hate crimes that terrorize and subordinate entire groups deprive them of their civil liberties (Bell, 2002; Herek, Cogan, \& Gillis, 2002; Matsuda, Lawrence, Delgado, \& Crenshaw, 1993), and hate crime laws reflect the state's recognition of and protection of the civil rights of all groups.

\section{Perpetrators}

In addition to classifying crimes, is there a way in which grouping perpetrators will allow prediction of treatment response, or recidivism? Can we create a typology of offenders that will allow better hypothesizing about the degree of preplanning and the degree of bias? If, in fact, hate-based assaults are much more destructive than comparable assaults that are not motivated by bias, why is that? Research about perpetrators should guide policy regarding prediction, prevention, and intervention where possible.

Classification of offenders. In order to describe offenders, various classification schemes have been proposed. For example, Levin and McDevitt (1995) identified three types of offenders based on motivation, a typology recently updated to four categories (McDevitt et al., 2002). These include "thrill-motivated" offenders who are motivated by excitement, bragging rights, and peer acceptance; "defensive" offenders who perceive outsiders as a threat to their way of life, their community, and their privileges; "mission" offenders, defined as those committed to a supremacist ideology; and "retaliatory" offenders, inspired to avenge perceived assaults on the group. Ezekial (1995) took a qualitative approach to the study of hate group members (who may or may not have perpetrated crimes). He noted a variety of types of members, including those simply seeking group membership and belonging, those who were more interested in crime opportunities than ideology, and those who were "true believers."

Existing research concerning violent offenders in general may be useful in understanding perpetrators of violent bias crimes. For example, bias-motivated violence should be compared with other types of youth violence, and the demographics of hate crime perpetrators (e.g., age, sex) can be compared with perpetrators of other, similar types of crime. More research is needed to better 
understand the distinctions, if any, between offenders who commit property crimes and those who commit crimes against persons; the distinctions between offenders who are part of a racial- or ethnic-based gang and those belonging to organized hate groups; and the characteristics of those who commit crimes alone. More needs to be understood about why some offenders repeatedly commit bias crimes and others do not. McDevitt et al. (2002) suggest that thrill-seeking offenders may be deterred from repeating the crime if there is a strong societal response, whereas defensive or mission offenders are less easily deterred. It seems reasonable to expect that strength of bias ideology predicts recidivism; however, this is only speculation. More research is needed.

What is known about violent criminals in general may also be useful in guiding intervention and punishment of hate crime perpetrators, including our knowledge of psychopathy (Hare, 1991), of societal, biological, and familial variables (Raine, 1993), and of predictors of recidivism and treatment outcomes for violent offenders (Quinsey, Harris, Rice, \& Cormier, 1998).

What creates an offender? Associated with questions of classification are questions of cause. Ezekial (1995) makes several fascinating observations about the "recruits" into a small hate group in Detroit. They are almost exclusively young men. Of the 20 members, 18 had lost a parent (usually the father) to divorce or separation when young (median age was 7). All were growing up in a context of frail or nonexistent community connections, with few ties to siblings or peers other than contacts that occurred in school. Many, if not most, had dropped out of high school.

Ezekial's (1995) observations about these individuals are mirrored by many of the theories about causes of involvement in hate activity, succinctly summarized by Turpin-Petrosino (2002). Hate group members "are frequently described as youth who are academically unsuccessful, have poor family relationships, and are insecure, alienated, impotent, and angry ... backgrounds of family violence and child and substance abuse are not uncommon" (p. 284). Deprivation theory suggests that hate ideology fulfills needs for social affiliation and group membership in youths who are emotionally and economically vulnerable. Interpersonal bonds theory suggests that recruitment into hate ideology occurs through social networks. Once social ties are established, the new member is introduced into group ideology, which maintains the social tie.

Unfortunately, relative to youth offenders, we know even less about older people who commit hate crimes. Results of preliminary analyses of data from an ongoing study of all hate crime reports collected by the LAPD appear to be contrary to the perception that hate crime perpetrators are typically juvenile offenders. Of the 814 records analyzed so far (of which only 483 reports indicated perpetrator age) the average perpetrator was 30 years old $(S D=13.54)$. The mean age of perpetrator varied with the nature of the hate crime: The oldest perpetrators were those who selected victims on the basis of religion $(n=35$, $M=38.26$ years, $S D=16.66)$. In contrast, perpetrators who selected victims on the basis of race were, on average, 29 years old $(n=315, M=29.83$ years, $S D=13.46$ ), and those who selected on the basis of sexual orientation were 28 years old on average $(n=120, M=28.33$ years, $S D=11.76)$ (Dunbar, personal communication, September 16, 2002). This is very preliminary data, of course, and it remains to be seen what emerges as the study continues. 
Discomfort with social change may be involved in hate attitudes (Green, Strolovich \& Wong, 1998; Umemoto \& Mikami, 2000). An intriguing study by McGregor, Zanna, Holmes, and Spencer (2001) found that, under some circumstances, "the threat of personal uncertainty appears to cause a kind of situational authoritarianism involving exaggerated intergroup bias and attitude hardening" ( $p$. 483) toward social issues and groups. "Shifting toward being a know it all, jingoist or zealot helped provide solace in the face of uncertainty" (McGregor et al., 2001, p. 484). Whether this phenomenon in any way helps to explain hate crimes remains to be seen, although it is consistent with the surge in hate crimes found when there is rapid in-migration of a minority group (Green et al., 1998), and consistent with the finding that white supremacists and hate crime perpetrators are more obsessed with diversity, race mixing, immigration and gender role changes than the general public (Green, Abelson, \& Garnett, 1999). The various theories seem to converge, but research to better understand the causes needs to continue.

Environmental influences beyond our control may contribute to or exacerbate hate crime occurrence. The September 11, 2001 (9/11) attacks on the World Trade Center and the Pentagon appear to have triggered bias incidents and crimes against those perceived to be Arab or Muslim. In the 4 months after 9/11, more than 1,450 bias crimes and incidents against perceived Muslims were reported, including eight deaths (Council on American-Islamic Relations, 2002), a dramatic increase from the 240 to 366 reported per year from 1997 to 2000 (Nimer, 2001). The relative contribution made by such news events compared with other factors predicting bias crime needs further examination. The role of strong antihate crime policies becomes even more crucial in these circumstances.

In some cases, genuine mental illness may play a contributory role. In a recent California case, a woman purposefully ran over and killed a Mexican American man. She was charged with a hate crime based on the statements of some witnesses. During the investigation it emerged that she had a number of severe psychiatric problems, including poorly controlled bipolar disorder. She had, prior to the crime, been declared a danger to herself or others 17 times, had been frequently hospitalized, and at the time of the incident was apparently in a manic state. According to a witness who knew the victim, "everyone thought she was nuts... I would rather say it was her mental state rather than anything else ... even the employees who loved Jesus [the victim] didn't see it as a race issue" (Connelly \& Teetor, 2001, p. 27). While this case has not yet gone to trial, it appears to meet more closely the criteria typically accepted as indicating psychiatric incompetence. One hopes that hate crime laws allow for the distinction to be made between bias-motivated violence and violence that is a consequence of genuine mental illness.

Prevention and intervention with offenders. Many of the proposed prevention strategies suggest "trying to establish ways for kids of middle-school age or younger to find mentorship and membership in constructive alternatives" (Ezekial, 1995, p. 323). The California Education Code requires the school curriculum to include human relations education, "with the aim of fostering an appreciation of the diversity of California's population and discouraging the development of discriminatory attitudes and practices" (California State Attorney General's Office, 2001). Yet if the theories described above are correct, simply 
adding diversity training classes seems unlikely to prevent vulnerable young people from being drawn to hate ideology. A twist to diversity training has been proposed, in which an emphasis of "how racism and bigotry impedes Whites economically, politically and socially" (Turpin-Petrosino, 2002, p. 298) is added - an interesting idea in light of previously reviewed research suggesting that prejudice is frequently correlated with perception of one's self as victimized by the "other." Still, we do not know if preventing prejudicial attitudes in the majority of vulnerable youth will decrease bias-motivated behavior (violence), which is committed by a small minority of people who have prejudicial attitudes.

In California, according to Penal Code $422.95 \mathrm{a} \& \mathrm{~b}$, "the court may order the defendant to complete a class or program on racial or ethnic sensitivity or other similar training in civil rights if such class or program is available as a condition of probation, to make payments or other compensation to a community-based program or local agency that provides services to victims of hate violence, and to reimburse the victim for reasonable costs of counseling and other expenses." Similarly, Massachusetts law requires that hate crime offenders receive a mandatory diversity awareness program as part of their sentencing (G.L. 265, § 39). Unfortunately, programs purporting to create diversity awareness in offenders are typically adapted from diversity training programs designed for nonoffenders in a school or work setting-hardly comparable audiences. None of these programs have demonstrated efficacy empirically. Research is needed to understand when, if ever, these programs work, and for which types of offenders.

Both McDevitt et al.'s (2002) and Ezekial's (1995) typologies seem to suggest some gradation in threat, culpability, and receptivity to rehabilitation. So-called mission offenders who are leaders and instigators, and who have clear and committed bias ideologies would seem more culpable and less able to be rehabilitated than less willing participants who are peripheral or unwilling participants in a bias crime and less committed to the ideology.

The question of who benefits from what type of rehabilitation, about which we know so little, takes on added importance when one considers that for psychopathic offenders therapy may increase dangerousness (even if it can decrease dangerousness of nonpsychopathic offenders). A study of an intensive therapeutic community program developed for violent offenders (Rice, 1997) showed that "treated psychopaths had significantly worse outcomes than their untreated counterparts, whereas the reverse was true for the nonpsychopaths ... it is possible that, whereas the nonpsychopaths in the program learned how to be more empathic and concerned about others, the psychopaths simply learned how to appear more empathic.... In the absence of any true empathy, the better manipulation skills of the treated psychopaths allowed them to use and abuse others [in both violent and nonviolent ways]" (p. 415). Policies developed to rehabilitate perpetrators of hate crimes, particularly violent hate crimes, must take this finding into account by mandating careful selection of individuals for rehabilitation.

\section{Victims of Hate Crimes}

Intervention with individual victims. Current research indicates that criminal victimization in general can leave victims with significant psychological distress 
(Cook, Smith, \& Harrell, 1987; Frieze, Hymer, \& Greenberg, 1987; Kilpatrick et al., 1985). Variables proposed to explain the mechanism of psychological distress include, for example, loss of a sense of self, loss of a sense of safety, feelings of inequity (Frieze et al., 1987), degree of violence, and prior victimization experiences (Norris, Kaniasty, \& Scheer, 1990).

Basic research with victims of bias crimes is needed to see if these variables are similarly relevant in understanding the psychological impact of bias crimes. It has been proposed that victims of violent bias crime suffer more psychological injury on average than victims of violent, nonbias motivated crimes. If differential impact is established, psychological research should be undertaken to understand the mechanisms by which this occurs. Janoff-Bulman's $(1979,1982)$ research with rape victims and coping was cited in this paper-this and other models should be more thoroughly examined. The paucity of research thus far must be emphasized. As mentioned above, the psychological literature is quite sparse, and what research exists tends to have been conducted within the past 5 to 10 years.

We know from existing studies of victims of crimes that the minority of crime victims seeks mental health treatment, perhaps 2-7\% (Friedman, Bischoff, Davis, \& Person, 1982; Knudten, Meade, Knudten, \& Doernier, 1977) or 9-18\% in the case of more violent crimes (Golding, Stein, Siegel, Burnam \& Sorenson, 1988). Variables found to increase seeking of professional help include internal locus of control, social support, level of distress, and the presence of violence in the commission of the crime (Norris et al., 1990). We know little about predictors of seeking mental health treatment by victims of violent hate crimes. For example, if the presence of social support increases help-seeking in nonhate crimes, what happens if the victim of a bias crime is too embarrassed, too fearful, or too closeted to seek social support? Research is needed that will explore these issues. Policies that facilitate treatment (in many cities, policies are in place to facilitate treatment of rape victims) would be helpful.

Additionally, treatments specifically for hate crime victims that are theoretically grounded and have demonstrated efficacy do not yet exist. Treatment models with demonstrated empirical support that have been developed for posttraumatic stress disorder and for rape victims may be readily adapted to this population. However, caution is warranted, particularly as some popular treatment modalities used for trauma (e.g., eye movement desensitization and reprocessing [EMDR], Shapiro, 1989a, 1989b, 1991; or critical incident stress debriefing [CISD], Mitchell \& Everly, 1996; Mitchell, Everly, \& Mitchell, 1999) may have overstated efficacy (see, e.g., Davidson \& Parker, 2001, on EMDR research) or may in some cases harm patients (see, e.g., Carlier, Voerman, \& Gersons, 2000; Gist, Lubin \& Redburn, 1998; Gist \& Woodall, 1999; Mayou, 1999; and Mayou, Ehlers, \& Hobbs, 2000, on CISD research).

Intervention at a community level. In Wisconsin v. Mitchell, the justices mentioned that hate crimes are "thought to be more likely to provoke retaliatory crimes ... and incite community unrest." We have argued in this article that hate violence may create greater community distress and may increase risk for future attacks when victims fail to go to the police out of fear or anticipation of lack of support. The state of research on community impact of hate crimes and intervention strategies is in its infancy. Again, more information would be helpful. However, policy development cannot wait for research to be completed. 
Descriptive data for particular geographical regions are needed and could be helpful for prevention efforts. Geomapping is a promising technique that has been applied to Los Angeles County. Umemoto and Mikami (2000) used geographic information systems technology to map almost 2,000 reported bias incidents. Quantitative time series analyses identified demographic and socioeconomic variables that may help explain hate crime clustering. Relatively high-density clusterings of bias incidents were mapped and additional interviewing and archival research were conducted in two of the cluster areas. This innovative methodology reveals interesting patterns, for example, there was more frequent perpetrator membership in gangs where hate crimes cluster, yet "there is strong evidence" that "the major motive is not the defense of territorial boundaries against other gangs, but hatred towards a group defined by racial identification regardless of any gang related territorial threat" (Umemoto \& Mikami, 2000).

Perhaps improved data collection could allow rapid mapping of clusters and rapid response. Information about demographic shifts could possibly assist in prediction and prevention of hate crime. We know that intergroup violence is likely to increase following particular patterns of outgroup migration into communities traditionally inhabited by another group. Green, Stolovich, and Wong (1998) found that hate crimes surge when there is a rapid in-migration of a minority group into a predominantly White area, and that the surge is greater when the area was formerly $90 \%$ white relative to when the area was formerly $50 \%$ White: "What matters is population growth and the racial context in which it occurs." Green et al. tested this hypothesis in various New York City area communities by examining in-migration patterns of different groups (Asian, Latino, Black) and corresponding rates of hate crime. Similarly, Umemoto \& Mikami (2000) examined patterns of in-migration of Latinos into formerly Black communities in Los Angeles. They found evidence in support of this hypothesis. If intergroup conflict will almost inevitably occur when certain patterns of demographic change are present, policies may be developed that will allow for preventative responses.

One avenue of intervention is improved relationships between members of minorities and the local police. Hate crimes are likely to be underreported (Berrill, 1992; Herek, 1989). The reasons may include concerns about police responsivity, desire to avoid drawing attention to oneself, fears of secondary victimization, embarrassment and shame, and so on. Community interventions to build relationships between community leaders and community organizations and the police would do much to alleviate the problem. The McDevitt et al. (2000) report recommends building trust between members of minority communities and local police, improvement of law enforcement agencies' ability to respond to victims reporting hate crimes, improvement of ease with which national data can be used by local law enforcement, and the increased use of supplementary data (such as from nongovernmental organizations) to illuminate the degree to which bias crimes are not reported to the police.

However, the concern that increased racial tension may be a result of hate crime laws has not, to date, been documented. Furthermore, survey data published in California appear to indicate improved intergroup relationships. Obviously this improvement cannot be attributed only to the presence of hate crime laws. However, 
clearly this finding fails to prove the opposite point; that is, it does not show a decrease in intergroup relations during the time when hate crime laws are on the books.

\section{Conclusion}

In 1993, the U.S. Supreme Court ruled in favor of penalty enhancements for hate-based crimes. Some individual states have enacted their own hate crime legislation. Critics of these statutes often invoke a variety of psychological constructs in their objections. However, when psychological theory and research are brought to bear on these objections, their validity diminishes. Psychology has much to contribute to the definition and measurement of hate intent and motivation and to the study and treatment of perpetrators and victims and the communities to which they belong.

The goal of this article is to draw on the psychological literature to address those objections to hate crime statutes that implicitly or explicitly invoke psychological constructs including attitudes, motivation, behavior, and learning. Although the state of research as it now exists is quite incomplete, and many of the studies mentioned are still in progress, evidence that we have thus far suggests that hate-motivated crimes may be more severe in nature and in impact, and that hate-based crimes may be qualitatively different than other crimes. Clearly, the greatest weakness of the research cited is the preliminary nature of the area of inquiry, and, consequently, the lack of replications and the number of unanswered questions. Furthermore, one cannot have faith that statistics collected nationally by law enforcement truly capture the extent of the problem. It is hoped that these problems will be addressed in the future, as data collection by law enforcement improves and research studies find their way into the literature. It is also hoped that the debate about hate crime laws will be informed by research findings rather than by sensationalism, politics, or personal prejudices and biases.

\section{References}

Adams, H. E., Wright, L. W., \& Lohr, B. (1996). Is homophobia associated with homosexual arousal? Journal of Abnormal Psychology, 105, 440-445.

Akiyama, Y., \& Nolan, J. J. (1999, October). The Hate Crime Statistics Act of 1990: Developing a process for measuring and predicting the occurrence of hate crime. Paper presented at the meeting of Hate Crimes: Research, Policy and Action, Los Angeles.

Allport, G. W. (1958). The nature of prejudice. Reading, MA: Addison-Wesley.

American Psychiatric Association. (2000). Diagnostic and statistical manual of mental disorders (4th ed., text revision). Washington, DC: Author.

Anastasi, A., \& Urbana, S. (1997). Psychological testing (7th ed.). New Jersey: Prentice Hall.

Bane Civil Rights Act. California Civil Code § 52.1, Penal Code § 422.6 et seq. (2001).

Bell, C. (2002, August). African American responses to 9-11. Paper presented at the 110th Annual Convention of the American Psychological Association, Chicago.

Berk, R. A. (1990). Thinking about hate-motivated crimes. Journal of Interpersonal Violence, 5, 334-349.

Berkowitz, L. (1993). Aggression: Its causes, consequences and control. Philadelphia: Temple University Press.

Berrill, K. T. (1992). Antigay violence and victimization in the United States: An 
overview. In G. Herek \& K. Berrill (Eds.), Hate crimes (pp. 19-45). Thousand Oaks, CA: Sage.

Billig, M. (1985). Prejudice, categorization and particularization: From a perceptual to a rhetorical approach. European Journal of Social Psychology, 15, 79-103.

Black, R. W. (1999, October). Judge criticizes gay panic defense [Electronic version]. Associated Press.

Blumer, H. (1958). Race prejudice as a sense of group position. Pacific Sociological Review, 1, 3-7.

Blumer, H. (1965). Industrialization and race relations. In G. Hunter (Ed.), Industrialization and race relations: A symposium (pp. 228-229). New York: Oxford University Press.

Bobo, L. D. (1999). Prejudice as group position: Microfoundations of a sociological approach to racism and race relations. Journal of Social Issues, 55, 445-472.

Boeckmann, R. J., \& Turpin-Petrosino, C. (2002). Understanding the harm of hate crime. Journal of Social Issues, 58, 207-226.

Boyd, E. A., Berk, R. A., \& Hamner, K. M. (1996). "Motivated by hatred or prejudice": Categorization of hate-motivated crimes in two police divisions. Law \& Society Review, 30, 819-850.

Cal. Penal Code $\S 1170.75 \& \S 190.2(a)(16)$ (1999).

California State Attorney General's Office. (2001). Unlawful discrimination: Your rights and remedies - civil rights handbook. http://caag.state.ca.us/publication/civilrights/ 01Crhandbook/.pdf [Retrieved June 15, 2004]

Carlier, I. V., Voerman, A. E., \& Gersons, B. P. (2000). The influence of occupational debriefings on post traumatic stress symptomatology in traumatized police officers. British Journal of Medical Psychology, 73, 87-98.

Chuang, H. T., \& Addington, D. (1988). Homosexual panic: A review of its concept. Canadian Journal of Psychiatry, 33, 613-617.

Church Arson Prevention Act of 1996. 104 ${ }^{\text {th }}$ Cong. 2d Session H.R. 3525, amending 18 U.S.C. $\S 247$.

Clark, W. A. V. (1993). Neighborhood tipping in multiethnic/racial context. Journal of Urban Affairs, 15, 161-172.

Cline, F. X. (2001, September 26). In hills far from the Taliban, faces of hate and compassion. The New York Times, B6.

Commonwealth v. Carr, 580 A.2d 1362, 1363 (Pa. Super. Ct. 1990).

Commonwealth v. Gilchrist, No. 06-9763, 06-9764 (Suffolk Super. Ct., Mass. April 17, 1989).

Comstock, G. (1991). Violence against lesbians and gay men. New York: Oxford University Press.

Comstock, G. D. (1992). Dismantling the homosexual panic defense. Law \& Sexuality: A Review of Lesbian and Gay Legal Issues, 2, 81-102.

Connelly, L., \& Teetor, P. (2001, October 11). Against her will. Easy Reader, 32(7), 1, $26-28$.

Cook, R. F., Smith, B. E., \& Harrell, A. V. (1987). Helping crime victims: levels of trauma and effectiveness of service. Washington, DC: U.S. Department of Justice, National Institute of Justice.

Cooper, J., \& Fazio, R. H. (1984). A new look at dissonance theory. In L. Berkowitz (Ed.), Advances in experimental social psychology (Vol. 17, pp. 229-264). Orlando, FL: Academic Press.

Cornell, D. G., Warren, J., Hawk, G., Stafford, E., Oram, G., \& Pine, D. (1996). Psychopathy in instrumental and reactive violent offenders. Journal of Consulting and Clinical Psychology, 64, 783-790.

Council on American-Islamic Relations. (2002). Number of incidents by category since 
September 11, 2001 (Online). Available: http://www.cair-net.org/html/by category .htm. [Retrieved January 19, 2002]

Craig, K. M. (1999). Retaliation, fear, or rage: An investigation of African American and White reactions to racist hate crimes. Journal of Interpersonal Violence, 14, 138-151.

Dahir, M. (1999, June 22). Homosexual panicking. The Advocate, p. 27.

Davidson, P. R., \& Parker, K. C. H. (2001). Eye movement desensitization and reprocessing (EMDR): A meta-analysis. Journal of Consulting and Clinical Psychology, 69, 305-316.

Delahanty, D. L., Herberman, H. B., Craig, K. J., Hayward, M. C., Fullerton, C. S., Ursano, R. J., \& Baum, A. (1997). Acute and chronic distress and posttraumatic stress disorder as a function of responsibility for serious motor vehicle accidents. Journal of Consulting and Clinical Psychology, 65, 560-567.

Devine, P. G. (1989). Stereotypes and prejudice: Their automatic and controlled components. Journal of Personality and Social Psychology, 56, 5-18.

Dilithium Press, Ltd. (1989). Webster's encyclopedic unabridged dictionary of the English language. New York: Author.

Douglas, J. E., Burgess, A. W., Burgess, A. G., \& Ressler, R. K. (1992). Crime classification manual: A standard system for investigating and classifying violent crimes. New York: Lexington Books.

Dressler, J. (1995). Understanding criminal law (Legal text series). New York: Matthew Bender. (Originally published in 1987).

Duckitt, J. H. (1991). The development and validation of a subtle racism scale in South Africa. South African Journal of Psychology, 22, 147-156.

Duckitt, J. H. (1992-1993). Prejudice and behavior: A review. Current Psychology: Research \& Reviews, 11, 291-307.

Dunbar, E. (1995). The assessment of the prejudiced personality: The Pr scale forty years later. Journal of Personality Assessment, 65, 270-277.

Dunbar, E. (2002). Signs and cultural messages of bias motivated crimes: Analysis of the hate component of intergroup violence. In H. Giles (Ed.), Law enforcement, communication and the community. Amsterdam, the Netherlands: John Benjamins.

Dunbar, E., King, T., \& Umemoto, K. (1999). Geo-mapping hate crimes and aggression analysis: Partnering behavioral science with law enforcement. Paper presented the 107th Annual Convention of the American Psychological Association, Boston, MA.

Dunbar, E., Quinones, J., \& Crevecoeur, D. A. (in press). Assessment of hate crime offenders: The role of bias intent in examining violence risk. Journal of Forensic Psychology Practice.

Dunbar, E., Saiz, J. L., Stela, K., \& Saez, R. (2000). Personality and social group value determinants of outgroup bias: A cross-national comparison of Gough's Pr/To scale. Journal of Cross-Cultural Psychology, 31, 267-282.

Dunbar, E., Sullaway, M., \& Krop, H. (2000). Behavioral, psychometric and diagnostic characteristics of bias-motivated homicide offenders. Paper presented at the 108th Annual Convention of the American Psychological Association, Washington, DC. [Retrieved September 20, 2001]

Ehrlich, H. J. (1973). The social psychology of prejudice. New York: Wiley.

Ettenborough, K., Klawonn, A., \& Leonard, C. (2001, September 17). Valley mourns apparent backlash killing. The Arizona Republic. Retrieved from www.azcentral.com/ archive.

Ezekial, R. (1995). The racist mind: Portraits of American neo-nazis and klansmen. New York: Viking Penguin.

Fazio, R. H., Jackson, J. R., Dunton, B. C., \& Williams, C. J. (1995). Variability in automatic activation as an unobtrusive measure of racial attitudes: A bona fide pipeline? Journal of Personality and Social Psychology, 69, 1013-1027. 
Fazio, R. H., Sanbonmatsu, D. M., Powell, M. C., \& Kardes, F. R. (1986). On the automatic activation of attitudes. Journal of Personality and Social Psychology, 50, $229-238$.

Federal Bureau of Investigation. (1999a). Hate crime data collection guidelines, revised. Washington, DC: Author.

Federal Bureau of Investigation. (1999b). Training guide for hate crime data collection. Washington, DC: Author.

Federal Bureau of Investigation. (1999c). Uniform crime reports: Hate crime reporting statistics. Washington, DC: Author.

Festinger, L. (1957). A theory of cognitive dissonance. Stanford, CA: Stanford University Press.

Fiske, S. T., \& Taylor, S. E. (1991). Social cognition (2nd ed.). New York: McGraw-Hill.

Friedman, K., Bischoff, H., Davis, R., \& Person, A. (1982). Victims and helpers: Reactions to crime. Washington, DC: U.S. Department of Justice, National Institute of Justice.

Frieze, I. H., Hymer, S., \& Greenberg, M. S. (1987). Describing the crime victim: Psychological reactions to victimization. Professional Psychology: Research and Practice, 18, 299-315.

Galster, G. C. (1990). White flight from racially integrated neighborhoods in the 1970s: The Cleveland experience. Urban Studies, 27, 385-399.

Garner, B. A. (Ed.). (1999). Black's Law Dictionary, abridged (7th ed.). St. Paul, MN: West.

Gerstenfeld, P. B. (1992). Smile when you call me that! The problems with punishing hate motivated behavior. Behavioral Sciences and the Law, 10, 259-285.

Gist, R., Lubin, B., \& Redburn, B. G. (1998). Psychosocial, ecological and community perspectives on disaster response. Journal of Personal and Interpersonal Loss, 3, $25-51$.

Gist, R., \& Woodall, S. J. (1999). There are no simple solutions to complex problems: The rise and fall of critical incident stress debriefing as a response to occupational stress in the fire service. In R. Gist \& B. Lubin (Eds.), Response to disaster: Psychosocial, community, and ecological approaches (pp. 211-235). Philadelphia: Brunner/Mazel.

Glenny, M. (1993). The rebirth of history: Eastern Europe in the age of democracy (2nd ed.). New York: Penguin Books.

Glick, B. S. (1959). Homosexual panic: Clinical and theoretical considerations. Journal of Nervous \& Mental Disease, 129, 20-28.

Goldfried, M. R., \& Davison, G. C. (1976). Clinical behavior therapy. New York: Holt, Rinehart \& Winston.

Golding, J. M., Stein, J. A., Siegel, J. M., Burnam, M. A., \& Sorenson, S. B. (1988). Sexual assault history and use of health and mental health services. American Journal of Community Psychology, 16, 625-644.

Gough, H. G. (1951). Studies of social intolerance II: A personality scale of antiSemitism. Journal of Social Psychology, 33, 247-255.

Gough, H. G., \& Bradley, P. (1993). Personal attributes of people described by others as intolerant. In P. M. Sniderman, P. E. Tetlock, \& E. G. Carmines (Eds.), Prejudice, politics, and the American dilemma. Stanford, CA: Stanford University Press.

Governor's Advisory Panel on Hate Groups. (2000). Final report. Sacramento, CA: Author.

Green, B. F. (1992). A primer of testing. In A. Kazdin (Ed.), Methodological issues \& strategies in clinical research. Washington, DC: American Psychological Association.

Green, D. P., Abelson, R. P., \& Garnett, M. (1999). The distinctive political views of hate crime perpetrators and white supremacists. In D. Prentice \& D. Miller (Eds.), Cultural 
divides: Understanding and overcoming group conflict (pp. 429-464). New York: Sage.

Green, D. P., Glaser, J., \& Rich, A. (1998). From lynching to gay bashing: The elusive connection between economic conditions and hate crime. Journal of Personality and Social Psychology, 75, 82-92.

Green, D. P., Strolovitch, D., \& Wong, J. (1998). Defended neighborhoods, integration, and racially motivated crime. American Journal of Sociology, 104, 372-403.

Gregory, S. S. (1994, June 6). Black rage: In defense of a mass murderer. Time Magazine, p. 143.

Grier, W., \& Cobbs, P. (2000). Black rage. Eugene, OR: Wipf \& Stock. (Originally published in 1968).

Haberman, Clyde. (2000, July 19). When talk is cheap and hateful. The New York Times, B4.

Hajnal, Z., \& Baldassare, M. (2001, January 4). Finding common ground: Racial and ethnic attitudes in California. Report by the Public Policy Institute of California, San Francisco.

Hamilton, D. L. (Ed.). (1981). Stereotyping and intergroup behavior: Some thoughts on the cognitive approach. Cognitive processes in stereotyping and intergroup behavior (pp. 333-353). Hillsdale, NJ: Erlbaum.

Hare, R. D. (1991). The Hare Psychopathy Checklist-Revised. Toronto, Ontario, Canada: Multi-Health Systems.

Hare, R. D., \& Hart, S. D. (1993). Psychopathy, mental disorder, and crime. In S. Hodgins (Ed.), Mental disorder and crime (pp. 104-115). Newbury Park, CA: Sage.

Hate Crime Prevention. Committee on the Judiciary (July 22, 1998). (Testimony of Jack McDevitt).

Hate Crime Prevention Act. (1999). S. 622, 106th Cong.

Hate Crime Sentencing Enhancement Act. Violent Crime Control and Law Enforcement Act, 280003 (Public Law 103-322), 108 Stat. 1796, 2096.

Hate Crime Statistics Act. (1990), 28 U.S.C. 534.

Hate Crimes Violence. 106th Congress, 1st session (August 4, 1999). (testimony of Frederick M. Lawrence). [Retrieved July 29, 2001 from www.house.gov/judiciary/ lawr0804.htm]

Hate Crimes Violence. 106th Congress, 1st session (August 4, 1999). (testimony of Heidi M. Hurd). [Retrieved July 9, 2001 from www.house.gov/judiciary/hurd0804.htm]

Herek, G. (1989). Hate crimes against lesbian and gay men: Issues for research and policy. American Psychologist, 44, 948-955.

Herek, G., Cogan, J., \& Gillis, R. (2002). Victim experiences in hate crimes based on sexual orientation. Journal of Social Issues, 58, 319-340.

Herek, G., Gillis, R., \& Cogan, J. (1999). Psychological sequelae of hate crime victimization among lesbian, gay, and bisexual adults. Journal of Consulting and Clinical Psychology, 67, 945-951.

Herek, G., Gillis, R., Cogan, J., \& Glunt, E. (1997). Hate crime victimization among lesbian, gay and bisexual adults. Journal of Interpersonal Violence, 12, 195-215.

Herpertz, S. C., Werth, U., Lukas, G., Qunaibi, M., Schuerkens, A., Kunert, J., Freese, R., Flesch, M., Mueller-Isberner, R., Osterheider, M., \& Sass, H. (2001). Emotion in criminal offenders with psychopathy and borderline personality disorder. Archives of General Psychiatry, 58, 737-745.

Hightower, E. (1997). Psychosocial characteristics of subtle and blatant racists as compared to tolerant individuals. Journal of Clinical Psychology, 53(4), 369-374.

Hill, J. L., \& Zautra, A. J. (1989). Self-blame attributions and unique vulnerability as predictors of post-rape demoralization. Journal of Social and Clinical Psychology, $8(4), 368-375$. 
Ilnytzky, U. (1999, April 7). Anti-gay attacks said more violent. The Associated Press (AOL News). [Retrieved June 19, 2004 from ftp://ftp.nyct.net/pub/users/tallpaul/ publish/story4/story932.txt]

In re Joshua H. (1993). 13 Cal. A 4th 1734, rev. den.

In re M. S. (1995). 10 Cal. 4th 698.

In re S. L. J. (Minn. 1978) 263 N.W. 2 d 412.

International Association of Chiefs of Police. (1998, June). Responding to hate crimes: A police officer's guide to investigation and prevention. Hate Crime in America Summit. Retrieved from www.theiacp.org/documents/index.cfm?fuseaction $=$ document\&document_id $=160$

Jacobs, J. B., \& Potter, K. (1998). Hate crimes: Criminal law and identity politics. New York: Oxford University Press.

Janoff-Bulman, R. (1979). Characterological versus behavioral self-blame: Inquiries into depression and rape. Journal of Personality and Social Psychology, 37, 1798-1809.

Janoff-Bulman, R. (1982). Esteem and control bases of blame: "Adaptive" strategies for victims versus observers. Journal of Personality, 50, 180-192.

Kahan, D. M. (1998). The anatomy of disgust in criminal law. Michigan Law Review, 96, $1621-1657$.

Karpinski, A., \& Hilton, J. L. (2001). Attitudes and the Implicit Association Test. Journal of Personality and Social Psychology, 81, 774-788.

Kelleher, K. (1999, November 8). The case against the notion of 'homosexual panic'. Los Angeles Times, E1.

Kempf, E. J. (1976). Psychopathology (Classics in Psychiatry Series). Manchester, NH: Ayer. (Original work published in 1920).

Kiel, F. W. (1965). The psychiatric character of the assailant as determined by autopsy observations of the victim. Journal of Forensic Science, 10, 269.

Kilpatrick, D. G., Best, C. L., Veronen, L. J., Amick, A. E., Villeponteaux, L. Q., \& Ruff, G. A. (1985). Mental health correlates of victimization: A random community survey. Journal of Consulting and Clinical Psychology, 53, 866-873.

Knudten, R. D., Meade, A. C., Knudten, M. S., \& Doernier, W. G. (1977). Victims and witnesses: The impact of their crime and their experience with the criminal justice system. Washington, DC: U.S. Department of Justice, National Institute of Justice.

Leonard, C., Walsh, J., Kelly, C., \& Collom, L. (2001, September 18). Sikhs voice outrage over Mesa hate killing [Electronic version]. Arizona Republic. [Retrieved September 21, 2001 from www.azcentral.com/archive]

Levin, B. (1999). Hate crimes: Worse by definition. Journal of Contemporary Criminal Justice, 15, 6-21.

Levin, B. (2002). From slavery to hate crime laws: The emergence of race and statusbased protection in American criminal law. Journal of Social Issues, 58, 227-246.

Levin, J., \& McDevitt, J. (1993). Hate crimes: The rising tide of bigotry and bloodshed. New York: Plenum Press.

Levin, J., \& McDevitt, J. (1995, August 4). The research needed to understand hate crime. The Chronicle of Higher Education, 41(47), B1-2.

MacDonald, A. (aka William Pierce). (1978). The Turner diaries. Washington, DC: National Alliance.

Matsuda, M. J., Lawrence, C. R. III, Delgado, R., \& Crenshaw, K. W. (1993). Words that wound: Critical race theory, assaultive speech, and the first amendment. Boulder, CO: Westview Press.

Mayou, R. A. (1999). Medical, social and legal consequences. In E. J. Hickling \& E. B. Blanchard (Eds.), The international handbook of road traffic accidents and psychological trauma (pp. 43-56). London: Pergamon (Elsevier Science Ltd.). 
Mayou, R. A., Ehlers, A., \& Hobbs, M. (2000). Psychological debriefing for road traffic accident victims. British Journal of Psychiatry, 176, 589-593.

McConahay, J. B. (1986). Modern racism, ambivalence and the modern racism scale. In J. F. Dovidio \& S. L. Gaertner (Eds.), Prejudice, discrimination and racism (pp. 91-125). Orlando, FL: Academic Press.

McConahay, J. B., Hardee, B. B., \& Batts, V. (1981). Has racism declined? It depends upon who's asking and what is asked. Journal of Conflict Resolution, 25, 563-579.

McConnell, A. R., \& Leibold, J. M. (2001). Relations among the Implicit Association Test, discriminatory behavior, and explicit measures of racial attitudes. Journal of Experimental Social Psychology, 37, 435-552.

McDevitt, J. (1999). Plenary keynote address. Paper presented at the Meeting of Hate Crimes: Research, Policy and Action, Los Angeles, CA.

McDevitt, J., Balboni, J. M., Bennett, S., Weiss, J. C., Orchowsky, S., \& Walbolt, L. (2000). Improving the quality and accuracy of bias crime statistics nationally: An assessment of the first ten years of bias crime data collection. Washington, DC: U.S. Bureau of Justice Statistics.

McDevitt, J., Levin, J., \& Bennett, S. (2002). Hate crime offenders: An expanded typology. Journal of Social Issues, 58, 303-318.

McGregor, I., Zanna, M. P., Holmes, J. G., \& Spencer, S. J. (2001). Compensatory conviction in the face of personal uncertainty: Going to extremes and being oneself. Journal of Personality and Social Psychology, 80, 472-488.

Mikkelson, K. W. (1999). California's civil and criminal laws pertaining to hate crimes. Retrieved from http://caag.state.ca.us/civilrights/htm/laws.htm.

Miller, B., \& Humphries, L. (1980). Lifestyles and violence: Homosexual victims of assault and murder. Qualitative Sociology, 169, 179.

Mison, R. B. (1992). Homophobia in manslaughter: The homosexual advance as insufficient provocation. California Law Review, 80, 133-178.

Mitchell, J., \& Everly, G. (1996). Critical incident stress debriefing-An operations manual. Ellicott City, MD: Chevron.

Mitchell, J. T., Everly, G. S., \& Mitchell, D. J. (1999). The hidden victims of disasters and vehicular accidents: The problem and recommended solutions. In E. J. Hickling \& E. B. Blanchard (Eds.), Road traffic accidents and psychological trauma. London: Pergamon (Elsevier Science Ltd.).

Model Penal Code (1985).

Morsch, J. (1991). The problem of motive in hate crimes: The argument against presumptions of racial motivation. Journal of Criminal Law and Criminology, 82, 659.

Ni, C. (1995, February 4). Two murder defendants also face charge of hate crime. Los Angeles Times, B1.

Nicholson, R. A., \& Kugler, K. E. (1991). Competent and incompetent criminal defendants: A quantitative review of comparative research. Psychological Bulletin, 109, 355-370.

Nimer, M. (2001). The status of Muslim civil rights in the United States: Accommodating diversity. Washington, DC: Council on American-Islamic Relations.

Noel, A. (2000). Hate violence statutes and the First Amendment. (chap. 7). In State Bar of California, Representing victims of hate violence in civil proceedings: A manual for attorneys on the Ralph and Bane Civil Rights Acts (4th ed.). Sacramento, CA: State Bar of California. [Retrieved from http://caag.state.ca.us/civilrights/ firstamend.htm]

Nolan, J. J., \& Akiyama, Y. (1999). An analysis of factors that affect law enforcement participation in hate crime reporting. Journal of Contemporary Criminal Justice, 15, $111-127$.

Norris, F. H., Kaniasty, K. Z., \& Scheer, D. A. (1990). Use of mental health services 
among victims of crime: Frequency, correlates and subsequent recovery. Journal of Consulting and Clinical Psychology, 58, 538-547.

O’Neil, A. W. (2000, September 19). Jury can hear Furrow's confession, judge rules. Los Angeles Times, B1.

Olatunji, B. O., Lohr, J. M., \& Meunier, S. A. (2002, June). Emotional mediators of homophobia: Implications for construct and psychometric validity. Paper presented at the meeting of the American Psychological Society, New Orleans, LA.

Ottensmen, J. R., \& Gleeson, M. E. (1992). The movement of whites and blacks into racially mixed neighborhoods: Chicago, 1960-1980. Social Science Quarterly, 73, 645-663.

Patterson, G. R. (1975). Families: Applications of social learning to family life (revised). Champaign, IL: Research Press.

People v. Superior Court, 896 P. 2 d 1387 (1995).

Perkins, R. M., \& Boyce, R. N. (1982). Criminal law, 86, (3rd ed.).

Pettigrew, T. F. (1998). Intergroup contact theory. Annual Review of Psychology, 49, 65-85.

Pettigrew, T. F. (2002, August). A Meta-analytic test and reformulation of intergroup contact theory. Paper presented at the 110th Annual Convention of the American Psychological Association, Chicago, IL.

Pettigrew, T. F., \& Meertens, R. W. (1995). Subtle and blatant prejudice in western Europe. European Journal of Social Psychology, 25, 57-75.

Quinsey, V. L., Harris, G. T., Rice, M. E., \& Cormier, C. A. (1998). Violent offenders: Appraising and managing risk. Washington, DC: American Psychological Association.

R.A.V. v. St. Paul, 505 U.S. 377 (1992).

Raine, A. (1993). The psychopathology of crime: Criminal behavior as a clinical disorder. San Diego, CA: Academic Press.

Ralph Civil Rights Act. California Civil Code 51.7 and 52. (2001). [Retrieved from http://www.leginfo.ca.gov/cgi-bin/displaycode?section $=$ civ\&group $=00001-01000 \&$ file $=43-53]$

Rice, M. E. (1997). Violent offender research and implications for the criminal justice system. American Psychologist, 52, 414-423.

Ruggiero, K. M., \& Taylor, D. M. (1997). Why minority group members perceive or do not perceive the discrimination that confronts them: The role of self esteem and perceived control. Journal of Personality and Social Psychology, 72, 373-389.

Salekin, R. T., Rogers, R., \& Sewell, K. W. (1996). A review and meta-analysis of the Psychopathy Checklist and Psychopathy Checklist-Revised: Predictive validity of dangerousness. Clinical Psychology: Science and Practice, 3, 203-215.

Selznick, N., \& Steinberg, S. (1969). The tenacity of prejudice: Anti-Semitism in contemporary America. New York: Harper \& Row.

Schick v. State, 570 N.E.2d 918, 921-922 (Ind. Ct. A 1991).

Shapiro, F. (1989a). Efficacy of the eye movement desensitization procedure in the treatment of traumatic memories. Journal of Traumatic Stress, 2, 199-223.

Shapiro, F. (1989b). Eye movement desensitization: A new treatment for post-traumatic stress disorder. Journal of Behavior Therapy and Experimental Psychiatry, 20, 211-217.

Shapiro, F. (1991). Eye movement desensitization \& reprocessing procedure: From EMD to EMDR - a new treatment model for anxiety and related traumata. Behavior Therapist, 14, 133-135.

Sing, J. J. (1999). Culture as sameness: Toward a synthetic view of provocation and culture in the criminal law. Yale Law Journal, 108, 1845-1884.

Smith v. Collin, 439 U.S. 916 (1978). 
Strom, K. J. (2001). Hate crimes reported in NIBRS, 1997-99. U.S. Department of Justice, Bureau of Justice Statistics Special Report. NCJ 186785.

Sullaway, M., \& Christensen, A. (1983). Couples and families as participant observers of their interaction. In J. P. Vincent (Ed.), Advances in Family Intervention, Assessment and Theory (Vol. 3, pp. 119-160). Greenwich, CT: JAI Press.

Sullaway, M., \& Dunbar, E. (1996). Clinical manifestations of prejudice in psychotherapy: Toward a strategy of assessment and treatment. Clinical Psychology Science and Practice, 3, 296-309.

Sullivan, A. (1999, September 26). What's so bad about hate: The illogic and illiberalism behind hate crime laws [Electronic version]. The New York Times Magazine. Retrieved from www.andrewsullivan.com/print/php?artnum $=19990926$

Tajfel, H. (1981). Human groups and social categories: Studies in social psychology. Cambridge, England: Cambridge University Press.

Tesner, M. A. (1991). Racial paranoia as a defense to crimes of violence: An emerging theory of self defense or insanity? B.C. Third World Law Journal, 11, 307-333.

Texas v. Johnson, 491 U.S. 397 (1989). [Retrieved from http://laws.findlaw.com/us/491/ 397.html]

Toolis, K. (1997, August 30). License to hate. The Guardian (London), T36.

Turner, N. (1998). What is a hate crime? Hate Crime in America Summit Recommendations. Retrieved from www.theiacp.org/documents/index.cfm?fuseaction=document\& document_id $=141$

Turpin-Petrosino, C. (2002). Hateful sirens ... Who hears their song? An examination of student attitudes toward hate groups and affiliation potential. Journal of Social Issues, $58,281-302$.

Umemoto, K., \& Mikami, C. K. (2000). A profile of race-bias hate crimes in Los Angeles County. Western Criminology Review, 2. Retrieved from http://wcr.sonoma.edu/ v2n2/umemoto.html

Watts, M. (2001). Aggressive youth cultures and hate crime: Skinheads and xenophobic youth in Germany. American Behavioral Scientist, 45, 600-615.

Weiss, J. C., Ehrlich, H., \& Larcom, B. (1991-1992). Ethnoviolence at work. The Journal of Intergroup Relations, 18, 28-29.

Wicklund, R. A., \& Brehm, J. W. (1976). Perspectives on cognitive dissonance. Hillsdale, NJ: Erlbaum.

Winer, A. S. (Spring, 1993). Hate crimes, homosexuals and the constitution. Harvard Civil Rights-Civil Liberty Law Review, 29, rev. 387.

Wisconsin v. Mitchell, 508 U.S. 476 (1993). [Retrieved from http://caselaw.lp.findlaw. $\mathrm{com} /$ scripts/getcase.pl?getcase.pl?court $=$ us $\& v o l=508 \&$ invol $=476]$

Wright, L. W., Adams, H. E., \& Bernat, J. (1999). Development and validation of the Homophobia Scale. Journal of Psychopathology \& Behavioral Assessment, 21, 337-347.

Zanna, M. P., \& Rempel, J. K. (1988). Attitudes: a new look at an old concept. In D. Bar-Tal \& A. W. Kruglanski (Eds.), The social psychology of knowledge (pp. 315-334). Cambridge, England: Cambridge University Press. 


\section{Appendix A \\ Selected Civil and Criminal Laws Pertaining to Hate Crimes in California}

\section{Statutes Defining Hate Crime}

The Ralph Civil Rights Act, Cal. Civ. Code $\$ \$ 51.7$ and 52 (2001), provides that it is a civil right for a person to be free of violence or its threat against the person or his or her property because of a person's race, color, religion, ancestry, national origin, political affiliation, sex, sexual orientation, age or disability or position in a labor dispute, or because a person is perceived to have one or more of these characteristics.

The Bane Civil Rights Act, Cal. Civ. Code $\S 52$ (2001), provides protection from interference by threats, intimidation, or coercion or for attempts to interfere with someone's state or federal statutory or constitutional rights. Proof of "hate motivation" is required. "Speech alone is not sufficient to support an action under the Bane Act, unless the speech itself threatens violence against a specific person or group of persons, and the person or group of persons against whom the threat is directed reasonably fears that, because of the speech, violence will be committed against them or their property and that the person threatening the violence had the apparent ability to carry out the threat" (Mikkelson, 1999).

\section{Penalty Enhancements}

Cal. Penal Code $\S 422.7$ (2001) provides that actions which are normally misdemeanors can become felonies if committed because of bigotry based on race, color, religion, ancestry, national origin, disability, gender, or sexual orientation or because the victim is perceived to have one or more of the above characteristics (with the exception of a person punished under Cal. Penal Code $\S 422.6$ (2001), which concerns damage to a person's property for reasons of bias).

Cal. Penal Code $\S 422.75$ (2001) provides for sentencing enhancements of 1 to 3 years for certain bias-motivated felonies against the aforementioned groups or against persons perceived to belong to one or more of the aforementioned groups, for heightened penalties of 2 to 4 years if the felony hate crime was committed in concert with another, adds a year if the defendant had a prior hate crime conviction, provides that use of firearm can be an aggravating factor, and provides that persons who commit or attempt to commit felonies against the property owned or rented by a public agency or private institution or the grounds adjacent thereto because the property is identified or associated with a member of or one of the aforementioned groups can be subject to a 1-3 year sentencing enhancement.

Cal. Penal Code $\S 190.2(a)(16)$ (2001) provides a death penalty or sentence of life in prison without possibility of parole for murder because of the victim's race, color, religion, nationality or national origin.

Cal. Penal Code $\S 1170.75$ provides additional punishment for felonies committed because of a victim's race, color, religion, etc., or because the victim is perceived to have one or more of the above-mentioned characteristics unless already punished under Cal. Penal Code $\S 422.75$ (2001) or Cal. Penal Code $\S 1170.8$ (2001).

\section{Remediation}

Cal. Penal Code $\S \S 422.95$ (a) and (b): Provides that if a person is granted probation for any Cal. Penal Code $\S \S 422.6,422.7,422.75,594.3$, or 11411 offense, the court may order the defendant to complete a class or program on racial or ethnic sensitivity or other similar training in civil rights if such class or program is available as a condition of 
probation, to make payments or other compensation to a community-based program or local agency that provides services to victims of hate violence, and to reimburse the victim for reasonable costs of counseling and other expenses. Any payments or compensation are in addition to restitution payments required under Cal. Penal Code $§ 1203.04$ (2001).

\section{Collection of Statistics}

Cal. Penal Code $\S 13023$ (2001) requires the Attorney General to collect statistical information on hate crimes and defines hate crimes as "any criminal acts or attempted criminal acts to cause physical injury, emotional suffering, or property damages where there is a reasonable cause to believe that the crime was motivated, in whole or in part, by the victim's race, ethnicity, religion, gender, sexual orientation, or physical or mental disability."

\section{Officer Standards and Training}

Cal. Penal Code $\S 13519.6$ provides that the Peace Officer Standards and Training Commission within the California Department of Justice shall develop guidelines and a course of instruction and training in hate crimes for law enforcement officers who are employed as peace officers or enrolled in a training academy for law enforcement officers. Hate crime for the purpose of this section means any act of intimidation, harassment, physical force, or the threat of physical force, directed against any person, or family, or their property or advocate, motivated either in whole or in part by the hostility to the real or perceived ethnic background, national origin, religious belief, gender, age, disability, or sexual orientation, of that person with the intention of causing fear and intimidation.

\section{Appendix B}

\section{Hate Crime Statistics Act (as amended, 28 USC § 534)}

$\S$ [Sec. 1.] (a) This Act may be cited as the "Hate Crime Statistics Act."

(b)

(1) Under the authority of $\S 534$ of title 28 , United States Code, the Attorney General shall acquire data, for each calendar year, about crimes that manifest evidence of prejudice based on race, religion, disability, sexual orientation, or ethnicity, including where appropriate the crimes of murder, nonnegligent manslaughter, forcible rape, aggravated assault, simple assault, intimidation, arson, and destruction, damage, or vandalism of property.

(2) The Attorney General shall establish guidelines for the collection of such data, including the necessary evidence and criteria that must be present for a finding of manifest prejudice and procedures for carrying out the purposes of this section.

(3) Nothing in this section creates a cause of action or a right to bring an action, including an action based on discrimination due to sexual orientation.

As used in this section, the term sexual orientation means consensual homosexuality or heterosexuality. This subsection does not limit any existing cause of action or right to bring an action, including any action under the Administrative Procedures Ace or the All Writs Act (5 U.S.C.S. 551 et. seq. or 28 U.S.C.S. 1651). 
(4) Data acquired under this section shall be used only for research or statistical purposed and may not contain any information that may reveal the identity of an individual victim of a crime.

(5) The Attorney General shall publish an annual summary of the data acquired under this section.

(c) There are authorized to be appropriated such sums as may be necessary to carry out the provisions of this section through fiscal year 2002 .

Sec. 2. (a) Congress finds that-

(1) the American family life is the foundation of American Society,

(2) Federal policy should encourage the well being, financial security, and health of the American family,

(3) Schools should not de-emphasize the critical value of American family life.

(b) Nothing in this Act shall be construed, nor shall any funds appropriated to carry out the purpose of the Act be used, to promote or encourage homosexuality. 